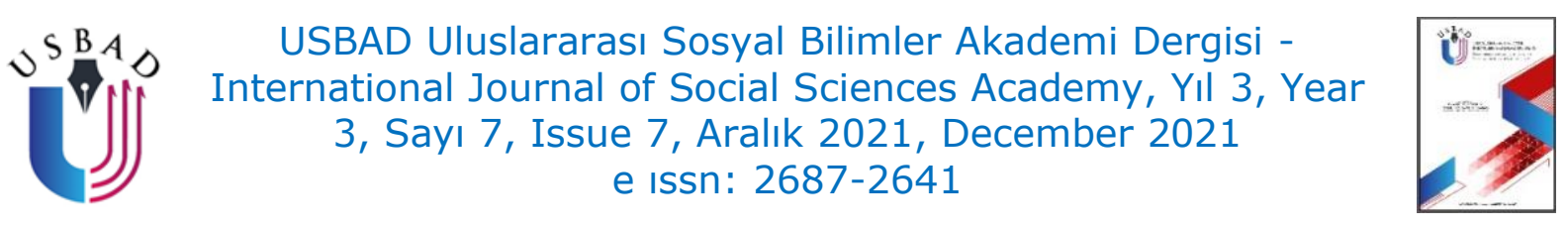

\title{
SOSYAL BİLİMLERE DENEY VE GÖZLEM İMKÂNI SUNAN BİR YÖNTEM ÖNERİSİ: ACP*
}

A Method Proposal That Offers the Opportunity of Experiment and Observation to Social Sciences: ACP

\author{
Abdulkadir BÜYÜKBİNGÖL \\ Dr., Marmara Üniversitesi, Gazetecilik, Bilişim, \\ PhD., Marmara University, Journalism, Informatics, \\ abdulkadir.buyukbingol@gmail.com \\ ORCID ID: 0000-0003-2411-9500 \\ Makale bilgisi | Article Information \\ DOI: $10.47994 /$ usbad. 1004236 \\ Makale Türü / Article Type: Araştırma Makalesi / Research Article \\ Geliş Tarihi / Date Received: 04.10.2021 \\ Kabul Tarihi / Date Accepted: 05.11.2021 \\ Yayın Tarihi / Date Published: 20.12.2021 \\ Yayın Sezonu / Pub Date Season: Aralık / December
}

Bu Makaleye Atıf İçin / To Cite This Article: Büyükbingöl, A. (2021). Sosyal

Bilimlere Deney ve Gözlem İmkânı Sunan Bir Yöntem Önerisi: ACP. USBAD Uluslararası Sosyal Bilimler Akademi Dergisi 3(7), 1500-1539.

İntihal: Bu makale intihal.net yazılımınca taranmıştır. İntihal tespit edilmemiştir. Plagiarism: This article has been scanned by intihal.net. No plagiarism detected.

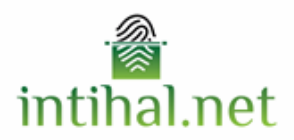

İletişim: Web: https://dergipark.org.tr/tr/pub/usbad mail: usbaddergi@gmail.com

\footnotetext{
${ }^{*}$ Bu makale yazarın doktora tezinin araştırma bölümüne dayanmaktadır.
} 
Öz: Endüstri 4.0 ile sanayide üretime yönelik verimliliğe odaklanılırken bireyin göz ardı edildiği belirtilmektedir. Birey merkeze alınarak geliştirilen Toplum 5.0 planına göre ise Endüstri 4.0'ın yarattığı hasarın da giderildiği mutlu ve müreffeh bir toplum oluşturulmak istenmektedir. Bu geleceğin inşasına yönelik kararlı bazı çalışmalar mevcuttur. Fakat Toplum 5.0'ın nasıl inşa edileceğine dair literatürde tatmin edici bir çalışmaya rastlanmamaktadır. Bu da Toplum 5.0'a ulaştırabilecek bir yöntem önerisinin gerekliliğini ortaya koymaktadır. Hali hazırdaki çalışmada sosyal bilişim bilimi sınırları içinde kalınarak bu geleceğe ulaştırabilecek bu yöntem açıklanmak istenmektedir. Analitik bir yaklaşımla ve nitel araştırma teknikleri kullanılarak yapılan araştırma sonucunda, ACP yaklaşımın üç farklı sistemin birleştirilmesiyle oluşturulan CPSS'in alt yapısını kullanarak yönetim ve kontrol sorunlarında etkili bilimsel çözümler sunduğu anlaşılmaktadır. Burada toplumsal etkileşimler modellenerek mikro görünümde gözlemlenebilmektedir. Ortamdaki işbirlikçi zekâ ile insanın ortak yönetimi ile bireysel, kurumsal ve yönetimsel yetenekler geliştirilebilmektedir. Bu durum tasarlanarak inşa edilmek istenen Toplum 5.0 gibi akıllı toplumlara ve ötesine ulaşmanın bu yöntemle mümkün olduğunu göstermektedir. Diğer taraftan sosyal sistemlerin modellenerek sosyal hesaplamanın mümkün olduğunu veren bu sonuç aynı zamanda, ACP'nin sosyal bilimler alanına deney ve gözlem yapabilme imkânı tanıdığı da ortaya çıkmaktadır.

Anahtar Kelimeler: Toplum 5.0, Akıllı Toplum, Sosyal Bilişim, ACP, CPSS, Sosyal Hesaplama

Abstract: It is stated that with Industry 4.0, the individual is ignored while focusing on productivity for production in the industry. According to the Society 5.0 plan, which was developed with the individual centered, it is desired to create a happy and prosperous society in which the damage caused by Industry 4.0 is also eliminated. There are some determined studies for the construction of this future. However, there is no satisfactory study in the literature on how to build Society 5.0. This reveals the necessity of a method proposal that can lead to Society 5.0. In the current study, it is desired to explain this method that can reach this future by staying within the boundaries of social information science. As a result of the research conducted with an analytical approach and using qualitative research techniques, it is understood that the ACP approach offers effective scientific solutions in management and control problems by using the infrastructure of CPSS, which is created by combining three different systems. Here, social interactions can be modeled and observed in the micro view. Individual, institutional and managerial abilities can be developed with the collaborative intelligence in the environment and the joint management of people. This situation shows that it is possible to reach smart societies such as Society 5.0, which is intended to be designed and built, and beyond with this method. On the other hand, this result, which shows that social calculation is possible by modeling social systems, also reveals that ACP provides the opportunity to make experiments and observations in the field of social sciences. 
Key Words: Society 5.0, Smart Society, Social Informatics, ACP, CPSS, Social Computing

\section{GİRİŞ}

1768 'de James Watt tarafından buhar makinesinin bulunmasıyla başlayan sanayi dönemiyle birlikte yaşanan gelişmeler, önceki dönemlerden bariz bir biçimde farklılaştıran özellik değişim hızıdır. Toffler, insanlığın gelişimini üçe bölerken yeni değişim dalgasının birkaç 10 yılda tamamlanacağını ifade etmesi (Toffler, 2008: 16), bu olgunun şiddetini göstermesi bakımından önemlidir. Toplumsal gelişmelerin, geçim biçimlerine göre çağlara ayrılmasından (Bell, 2012: 18) doğan avcı toplum, kırsal toplum, tarım toplumu ve ticari topluma bakıldığında çağ anlayışının aletlere göre şekillendiğinin görülmesi, bakışları teknolojik araçlara çevirmektedir. Yapılan yeni bir çalışmada (Keidanren, 2016) toplumsal aşamalar teknolojik aletlere uygun olarak numaralandırılmıştır. Buna göre Toplum 1.0 'da insanların doğal bir hayat sürdüğü ve ana geçim kaynağının avcılık olduğu tespit edilmiştir. Bu dönemde farklı amaçlarla bazı bitkiler de tanınmış ve birtakım tekniklerle yetiştirilmeye de başlanmıştır. Bir zan sonra yetiştiriciliğin ilerlemesi nedeniyle toplum tarım ile uğraşmaya başlamıştır. Bu dönem, insanlık gelişiminin ikinci aşamasını, yani Toplum 2.0 olarak adlandırılmıştır. İlk olarak İngiltere'de patlayan sanayi devrimiyle birlikte Toplum 3.0 dönemine girilmiştir. Buhar gücünden faydalanılması ile başlayan bu dönemin ikinci yarısından itibaren elektrik gücünün kullanılmasıyla ortayı çıkan teknoloji, insanların çalışma ve yaşam şekillerini önceki dönemlere göre daha derinden etkilemiştir. Bu dönemin sonunda geliştirilen bilgisayarlarla birlikte toplumsal gelişme aşamasının sonuncusu olan Toplum 4.0'a girilmiştir (Öztürk F., 2021: 32). Birinci endüstri devrimiyle birlikte inşa edilmeye başlanan modern uygarlığın yeni evresinde, sanayi toplumunun paradigmalarından bilgi2 toplumunun (information society) paradigmalarına doğru bir kayış yaşanmaktadır (Tonta ve Küçük, 2005: 8). Birleşmiş Milletler (BM) tarafından da 2003 yılında bilgi toplumu kavramı ilan edilerek yeni paradigmaya netlik kazandırılmıştır (DPT, 2008, s. 19). Burada günümüz insanı sahip olduğu nitelikli bilgiyi etkin siyasal, ekonomik ve sosyal örgütlenme ile doğru biçimde kullanarak yüksek bir refah seviyesine erişmeyi amaç edinmektedir (Nair, 2018: 42). Bilgi ve iletişim teknolojisi (BİT) alanındaki birikim, üretim, telekomünikasyon alt yapıları ve ar-ge için ayrılan bütçelere göre bir toplum bilgi toplumu nitelemesi yapılmaktadır. Bu anlamda Japonya, G. Kore, Çin gibi uzak doğu ülkelerinin yanı sıra ABD, Fransa, Kanada, Almanya, İngiltere, İsveç vb. ülkeler bu tür bilgi toplumlarına örnek gösterilebilir. Bilgi, bilişim ve yönetişim bu toplumların temel uğraş alanlarıdır ve bilgi 
giderek sanayi toplumundaki ağır sanayi ve petrol gibi üretim faktörlerinin yerini almaktadır (Yeşilorman ve Koç, 2014: 130).

Gelişimini bilginin işlenmesi üzerine kuran bilgi toplumunun temelinin BİT'en oluşması bilgi güvenliğini ve siber suçlar başta olmak üzere yeni tehditlere de zemin hazırlamıştır. Bu nedenle yeni olanaklardan faydalanılırken tehditlerin de bertaraf edilmesi için uluslararası iş birliklerinin geliştirilmesi, internetin mevcut güvenliliği ve devamlılığından ödün vermeden, "çok taraflı, meşru, şeffaf ve katılımcı" bir yapı inşasına dönük yeni mekanizmaların geliştirilmesi zaruri hale gelmiştir (DPT, 2008: 2). Yeni BİTle birlikte bu mekanizma işlemeye başlamıştır. Castells yeni mekanizmanın etkilerini açıklarken kalkınma ve üretkenliğin kaynağının bilgiyi üretme, işleme ve sembollerle iletişim teknolojisinde olduğunu ve buna bağlı olarak ikinci bin yılın sonlarına doğru, tarihsel önemde birkaç olayın insanın hayatını ve toplumsal görünümünü şekillendirdiğini anlatmaktadır. Ona göre dünyanın dört bir köşesindeki ekonomi, iş dünyası, devlet ve toplum arasında kurulan değişken bir geometri sistemiyle bu kurumlar küresel olarak birbirlerine bağlanmıştır. Böylece bu büyük ekonomilerin en değerli bölümleri birleştirilmiş ve gerçek zamanda tek bir birim gibi işleyen karşııkı ıağımlı bir sistem halini almıştır. Ayrıca giderek evrensel, sayısal bir dili konuşan yeni bir iletişim sistemi de hem Sayfa| 1503 kültürümüzün sözcükleri, sesleri ve imgelerinin üretimini ve dağıtımını küresel olarak entegre hale getirmekte hem de onları bireylerin kimliklerinin ve halet-i ruhiyelerine uygun kılmaktadır. Diğer yandan interaktif bilgisayar ağları da yeni iletişim biçimleri ve kanalları yaratarak hayatı şekillendirmekte ve aynı zamanda hayat tarafından şekillendirilip katlanarak büyümektedir (Castells, 2003: 1-4). Her şeyi küresel Information, Türkçede veri ile bilgi arasında bir aşamayı temsil etmektedir. Türkçeye, enformasyon olarak çevrilmiştir fakat information society, Türkçe literatürde yoğunluklu olarak bilgi toplumu şeklinde kullanılmaktadır. Biz de bu kullanımı takip edeceğiz olarak entegre hale getiren bu dil sayesinde ortak beğenileri keşfedenler, bir yandan kendilerini güncellerken, öte yandan interaktif bilgisayar ağlarında buluşup hayatı şekillendirebilmektedirler.

Yeni BİT'in etkilerini "dalga Teorisi" çerçevesinde açıklayan Toffler'ın, yaklaşık 40 yıl sonrası için beklediği gelişmeler Castells'i destekler niteliktedir. Burada artık yepyeni bir yaşam tarzını haber veren Toffler, çeşitli ve yenilenebilir enerji kaynakları bulunacak, eski fabrika düzenlerini etkisiz hale getiren yeni üretim süreçleri geliştirilecek, aile yapısı dahil birçok kurum değişecektir. Şimdiye ortaya atılan terimlerle ifade edilmesinde yetersiz kalınacağı bu gelecekte, derin sosyal çalkantılar ve yeniden yapılanma süreçleri gerçekleştirilecektir. Yepyeni bir uygarlığı 
temelden yaratma süreci olan bu geleceğe insanlık hazır olmazsa, büyük yıkımlar yaşanacaktır (Toffler, 2008: 16-17). Buna karşılık tarih boyunca insanın her türlü eyleminin mutluluk odaklı olduğunu bildiren Harari, yeni teknoloji ile bugün için olağan üstü olarak görülen bazı sonuçların elde edilmesini beklemektedir (Harari, 2016: 41). Harari'ye göre modern insan yeni dönemde, ölümü doğaüstü bir olay olarak yorumlamaktan ziyade teknik bir arıza olarak değerlendirecektir. Kurzweil ve Grey gibi fütüristlerle aynı görüşü paylaşarak 2050'de sağlıklı bir bedene ve sağlam bir banka hesabına sahip herkesin, her on yılda bir ölümsüzlük şansını yakalayabileceğini ummaktadır. Gelecekte patlayan bir bomba ya da çarpan bir kamyonun altında beden parçalanmadıkça, insanların sonsuza dek yaşayabileceklerinin işaretlerini görmektedir. Silikon Vadisi yatırımcılarından Peter Thiel'in, sonsuza kadar yaşama planı ve bir kısım uzmanların 2100 yılında insanların ölümü yeneceğine dair inancıyla görüşlerini desteklemektedir (Harari, 2016: 33-37).

Bu görüşler, her ne kadar More'un Ütopya'da, "bilim ve sanatla zenginleşen insan düşüncesinin özgürce gelişmesi" olarak tarif ettiği düşünce ile paralellik gösterse de (More, 2000: 128), süper akıllı toplumun inşa edilmek istendiği bir proje ile insanların hayallerini gerçekleştirebileceklerine dair bir dayanak belirmiştir. Mutlu ve müreffeh bir Sayfa | 1504 toplum oluşturmanın bir yolu olarak sunulan ve Japon İş Federasyonu Keidanren tarafından hazırlanan Toplum 5.0 projesi ile sürdürülebilirlik anlayışı içinde bu hedefin gerçekleştirebileceği mümkün görülmektedir (KEIDANREN, 2016), Endüstri 4.0'ın olanaklar üzerine bina edilmek istenen bu gelecekte toplumun insan, doğa ve teknoloji ile kurduğu yeni ilişki biçimi ve toplumsal eğilim ve örgütlenmelere bilgisayarlar ve DNA'ların mantığının yüklenmesiyle birlikte meydana gelen hızlı değişim yeni bir çağa girilmesini yakınlaştırmaktadır (Castells, 2003: 4). Fakat Toplum 5.0 olarak kavramlaştırılan (KEIDANREN, 2016; Wang vd., 2016; BM, 2018 vs.) bu geleceğin inşa edilmesine yönelik kapsamlı bir yöntem analizi yapılmamıştır. Bu nedenle sosyal bilişim bilimi sınırları içinde kalınarak ACP yaklaşımı tartışılmaktadır.

Geniş bir literatürün titizlikle tarandığı bu çalışmada siber-fiziksel sistemler (CPS; Cyber - Physical Systems) ve siber-fiziksel-sosyal sistemler (CPSS; Cyber - Physical - Social - Systems) gibi yapay toplum - bilişimsel deneyler - paralel yürütme şeklinde ifade edilebilen ACP (Artifical SocietyComputational Experiment-Parallel Execution) yaklaşımına alt yapı oluşturan teknolojiler incelenmektedir. Çalışmanın sonucunda Merton yasası, sosyal bilişim ve paralel zekâ üçgeninde insan-bilgisayar etkileşimin ACP yaklaşımıyla siber-fiziksel dünyadaki etkisi görünür hale 
getirilmektedir. Transhumanizm, dijitalleşme ve Endüstri 4.0 kavramlara eşdeğer bir kavram olabilecek nitelikteki Toplum 5.0'la ilgili yapılan bu katkı, hem sosyal bilimlerde yaşanan deney ve gözlem yapabilme sıkıntısına bir çözüm sunmakta hem de disiplinlerarası bilimsel çalışmalar ve uluslararası stratejik adımlara kavramsal bir köprü oluşturmaktadır.

\section{Toplum 5.0'ın Teknolojik Alt Yapısı}

Bütün düşüncelerin ve inançların doğru koşullar altında tutuşmak için bir kıvılcımı beklediğine tarih şahit gösterilmektedir (Castells, 2003: 29). Yeni bir fikir olarak geleceği birlikte inşa etmenin bir yolu şeklinde lanse edilen Toplum 5.0'da (KEIDANREN, 2016; 2017; Harayama, 2017, ITU-D, 2017; Fukuyama, 2018; Nakanishi ve Kitano, 2018; B20, 2019), kronik toplumsal sorunların çözülmüş olacağı beklentisi, bu geleceğe hazır olunmasını değerli kılmaktadır. Bu nedenle hem Toplum 5.0'a ulaşılmasına aracılık etmesi hem de bu döneme ulaşıldığında da etkili bir biçimde kullanılması beklenen CPS ve CPSS teknolojileri ile bunların üzerine oturtulan ACP yaklaşımı aşağıda tahlil edilerek Toplum 5.0'a ulaştırabilirliği tartışılmaktadır.

Savunma, enerji, altyapı, sağlık hizmetleri, üretim ve ulaşım gibi fiziksel sistemlere uygulanan BİT, bu sistemlerin kontrol, uyarlanabilirlik, Sayfa | 1505 özerklik, verimlilik, işlevsellik, korunurluk, güvenlik ve kullanılabilirlik özelliklerini de önemli ölçüde artmıştır. Bununla birlikte söz konusu fiziksel sistemlerin, gelecekte daha da gelişecek olan nesnelerin interneti, sosyal ağlar, bulut bilişim, büyük veri ve akıllı sistemler gibi teknolojilerin yardımıyla siber ortamda kontrol ve yönetimle ilgili büyük olanaklar sağlaması da beklenmektedir (Xiong vd., 2105: 320). Verilerin büyük ölçeklerde toplanıp iletilmesi, depolanarak analizi ve tüm dünya ile paylaşım maliyeti düştükçe, yeni inovasyonların önü açılacaktır (Nakanishi ve Kitano, 2018: 2-3).

Günümüzde doğal kaynakların tükenmesi, küresel ısınma, artan ekonomik eşitsizlik ve terörizm gibi küresel ölçekte zorluklar bu kabiliyetleri daha da önemli hale getirmiştir. Her düzeyde karmaşıklığın arttığı bu belirsizlik çağındaki dünyada, toplumsal sorunları çözmenin etkili ve verimli bir yolu olarak bu kabiliyetler kullanılabilir. Bu nedenle hem yeni bilgilerin sisteme eklenmesi hem de insan ve nesne ile gerçek ve siber dünya arasında bağlantılar kurulmasına aracılık ederek yeni değerlerin üretilmesini mümkün kılan BİT'in kullanımı önemsenmelidir. Endüstri 4.0 çıktıları da göstermektedir ki arka planında BİT ile desteklenen CPS yoluyla bilişsel ve fiziksel yeteneklerin artırılmasıyla yeni değerlerin üretilmesi mümkündür (Fukuyama, 2018: 47). 


\subsection{CPS (Cyber- Physical-Systems) Teknolojisi}

İlk olarak 1970'lerde hava kuvvetleri mühendisleri tarafından "gerçek uzaydan farklı, bilgisayar ortamında üretilen sanal alan"ı tanımlamak için kullanılan siber uzay, günümüzde fiziksel dünyamızla birleştirilerek yeni bir alan oluşturmuştur (Wang vd., 2016: 380). Bankacılık, imalat ve lojistik gibi endüstriyel altyapılarda 1990'lardan itibaren kullanımı gerekli görülen BİT, akıllı şehirler veya topluluklar gibi sosyal projelerde 2000'li yılların başından itibaren kullanılmaya başlanmıştır (CRDS, 2016: 66). İki sistemler bütününün (siber sistemler ve fiziksel sistemler) birleştirilmesiyle oluşturulan CPS'te, siber alan sibernetiğin uğraş alanındaki genel niteliği bildirmektedir (Işıklı ve Küçükvardar, 2016: 76). Fizik kanunlarına göre yönetilen ve sürekli çalışan fiziksel, doğal ve insan yapımı fiziksel sistemler siber alan tüm ölçek ve seviyelerde sıkı bir şekilde entegre edilmiştir (Gill, 2008: 4). CPS bileşenlerinin her ölçekte ağa bağlı olması ve bilişim araçlarının da tüm materyallere gömülü olması nedeniyle bu sistem, bilgisayarlı ve fiziksel eylemin hibritleşmesini temsil etmektedir. Hali hazırda mikro ve nano ölçekli siber ve fiziksel malzemeler, kontrollü bileşenler, iş birliği yapan tıbbi cihazlar ve sistemler, yeni nesil elektrik şebekesi, geleceğin savunma sistemleri, yeni nesil otomobiller ve akıllı otoyollar, esnek robotik üretim, yeni nesil hava araçları, hava sahası yönetimi gibi Sayfa | 1506 alanlarda bu sistemler kullanılmaktadır (Gill, 2008: 3).

CPS'lerin günlük yaşamda her yerde bulunabilmesi; kazadan önce müdahale, robotik cerrahi ve nano düzeyde kesin sonuç alma, savaş alanı, arama ve kurtarma, yangınla mücadele, trafik kontrolü, derin deniz keşifleri gibi erişilemez ortamlarda operasyon, enerji alanında verimlilik ve sağlık hizmetlerinin izlenmesi veya sunulması ile ilgili insan yeteneklerinin artırılmasına yardımcı olabilmektedir (Xiong vd., 2015: 321). Döngüsel bir iletişim vizyonunu ifade eden geribildirim kavramıyla da ilişkilendirildiği için CPS'e mekatronik ve bilişimi birleştiren bir sınır bilimi de denebilmektedir. Buradaki çalışmalar, insanların robotlarla entegre edilerek hibrit yardımcı uzuv dış iskeleti gibi araçlarla artırılmış insana ulaşılabilmektedir (Salgues, 2018: 7). 
Şekil 1: Bir CPS'in Genel Şeması (Humayed vd., 2017: 4).

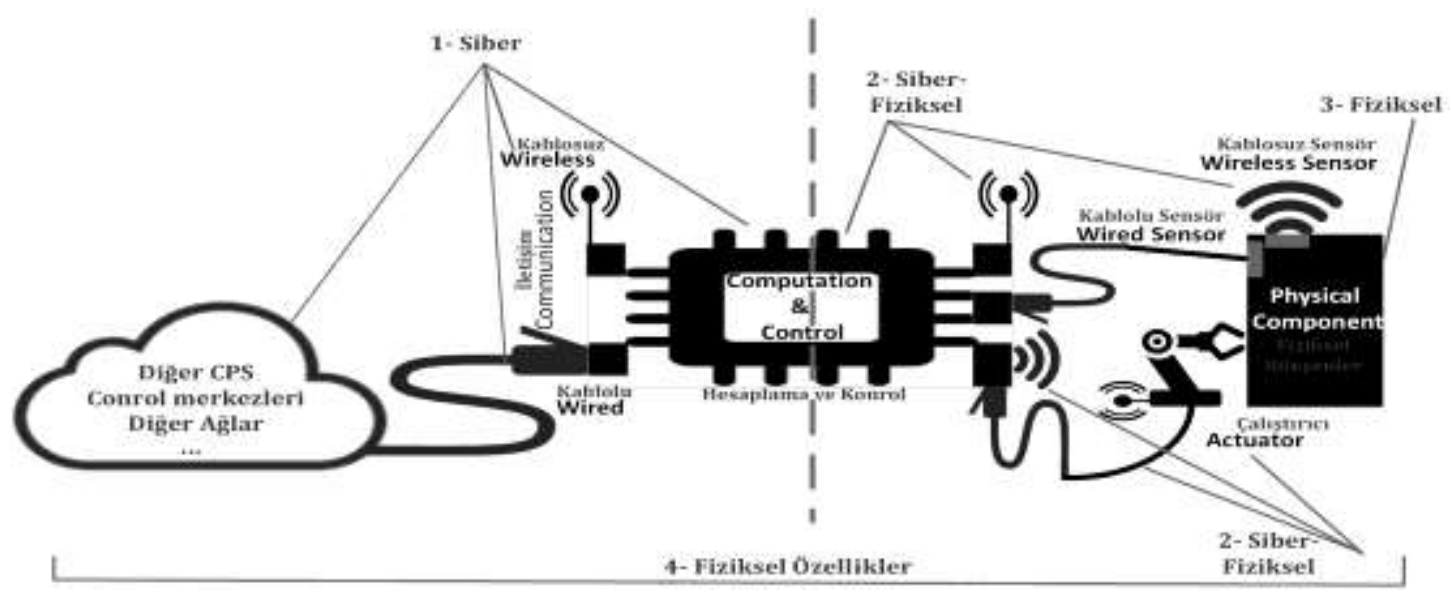

Bir CPS'in genel bir özetinin verildiği şekil 1'deki şemada sistemin temelde üç bileşenden oluştuğu anlaşılmaktadır: 1'de siber olarak belirtilen yönlerle iletişim özelliği gösterilmektedir. Kablosuz veya kablolu olabilen iletişim CPS'i, kontrol merkezleri gibi yüksek seviyeli sistemlere veya fiziksel dünyadaki daha düşük seviyeli bileşenlere bağlayabilmektedir. Siber-fiziksel yönleri belirten 2'de bilgisayarlı zekanın yerleştirildiği, kontrol komutlarının gönderildiği ve algılanan ölçümlerin alındığı yer olan hesaplama ve kontrol alanıdır. İzleme ve manipülasyon alanı olarak belirtilen 3'teki özellik ise fiziksel bileşenleri izlemek için sensörler aracılığıyla CPS'i fiziksel dünyaya Sayfa | 1507 ve bunları manipüle etmek için çalıştırıcılara bağlamaktadır. 1 ve 2'yi ayıran kesikli çizgi, fiziksel dünya ile etkileşimin varlığına veya yokluğuna bağlı olarak aynı bileşenin aynı anda hem siber hem de siber-fiziksel özellikler gösterebildiğini anlatmaktadır. Ek bilgi olarak verilen 4 'te ise bir CPS sisteminin herhangi bir parçasının fiziksel özelliklerinin yol açabileceği güvenlik sorunlarına dikkat çekilmektedir (Humayed vd., 2017: 4).

Şekil 2: Akıllı Endüstri'de kullanılan CPS şeması (Jørgensen, 2021).

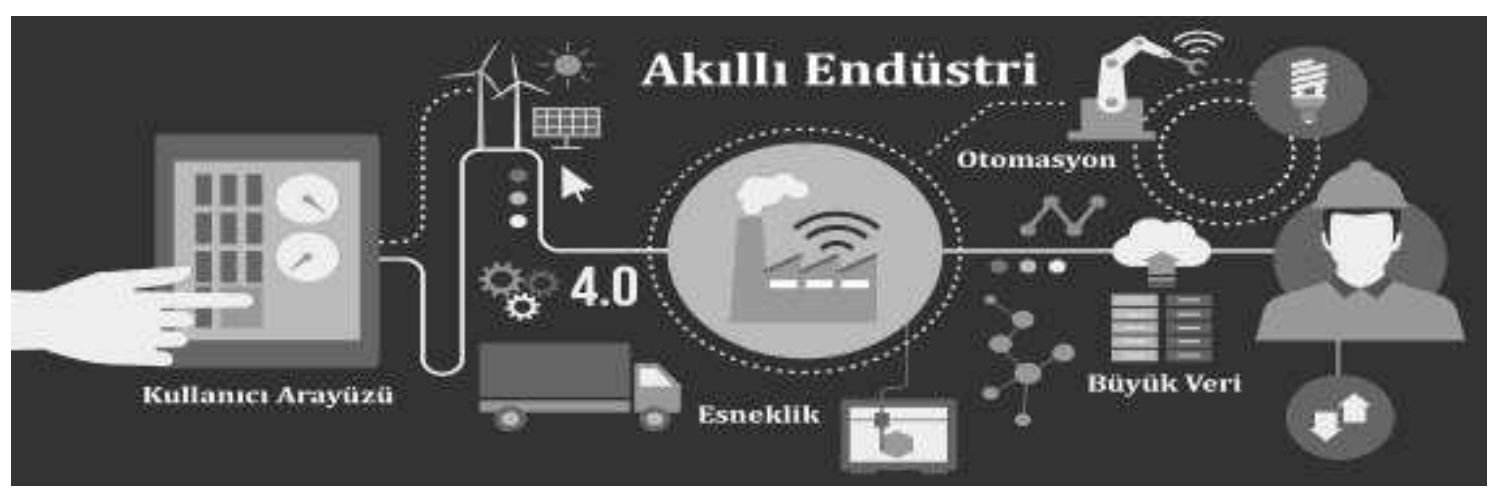

Şekil 2'deki şemada bir akıllı fabrikada CPS'in, kullanıcı ara yüzü tarafından harekete geçirilmesiyle toplanan büyük veri sayesinde sağlanan üretim esnekliği ve otomasyon özellikleri gösterilmektedir. Fabrika 
ortamında akıllı makineler, depolama sistemleri, otonom bilgi alışverişi yaparak eylemleri başlatan ve bağımsız kontrolü sağlayan üretim sistemleri CPS içermektedirler (Pereira vd., 2020: 3306). CPS teknolojisi ile sosyal üretimin mümkün olduğu anlatılan bir çalışmada müşterinin üretim sürecini izleyebildiği ve üreticiye gerçek zamanlı geri bildirimde bulunabildiği belirtilmektedir. Bu şekilde nihai ürünün özellikleri müşterinin isteklerine göre şekillenebilmektedir (Ding ve Jiang, 2016: 367-369). Ayrıca sosyal veriler ve ağ bağlantılı CPS aracılığıyla şehirle ilgili tüm verilerden yararlanarak geliştirilebilen uygulamalarla teknik işlemlerle hizmetin birlikte yürütülebildiği akıllı şehirlerde sürücüler ve yayalar hareket halindeyken sisteme trafik verilerini sağlayabilmektedirler (Costanzo vd., 2016).

Bir CPS'te yer alan alt düzey veri toplama ve üst düzey bilme işlevlerini birbirine bağlayan siber düzey ile bir grup makineden toplanan verilere dayanarak sistem bilgisinin özetlenmesiyle olası çalışma sistemleri, makine durumu, arıza modları ve bozulma bilgileri bir araya getirilerek bir modelleme yapılabilmektedir. Fiziksel bir nesnenin veya sistemin sanal kopyası olarak da adlandırılabilen bu dijital ikiz sayesinde edilen bilgiler gerçek nesneye uygulanarak maliyetler düşürülebilmektedir. Formula 1 otomobillerinin baştan sona sanal ortamda tasarlanmakta, sanal yarış pistlerinde test edilmekte ve gerçek otomobillerden elde edilen farklı veriler Sayfa | 1508 analiz edilerek sanal model yeniden tasarlanabilmektedir (Caner, 2020: 44).

Şekil 3: Sistem Odaklı Ürün Geliştirme Biçimi: Dijital ikiz (Nikolaev vd., 2018: 196)

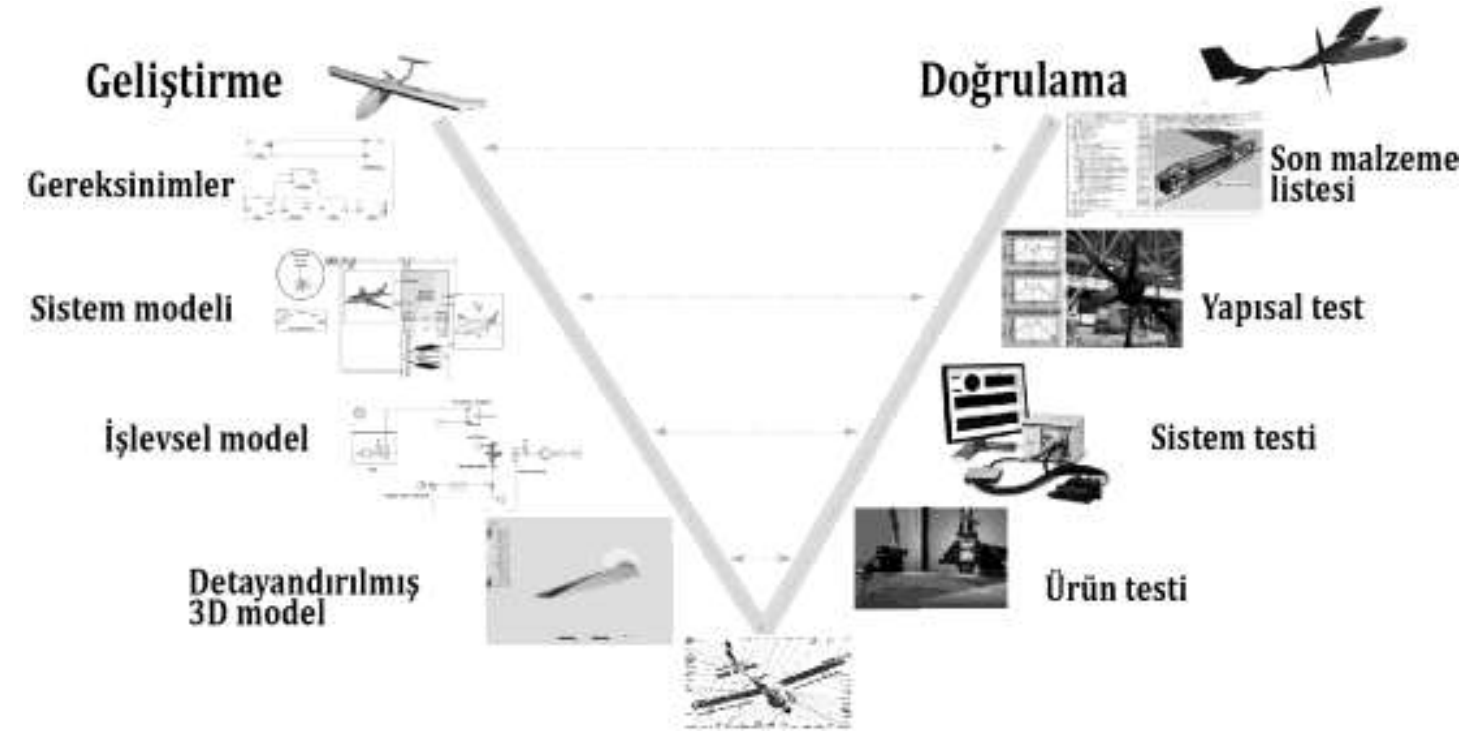

Şekil 3'teki v diyagramında bir uçak üretim fabrikasındaki sistem odaklı ürün geliştirme biçimi gösterilmektedir. Burada geliştirme ve doğrulama geliştirilen sanal ikiz yardımıyla eş zamanlı olarak ilerlemektedir. Bu şekilde gerçek ortam sanal ikizinde test edilerek elde edilen bilgiler ağ 
üzerinden senkronize olarak siber ikizle paylaşılmaktadır. Özellikle büyük veri ve $Y Z$ yardımıyla ürünün iyileştirilmesi, yeni ortamlara adapte edilmesi ve gelecekte ortaya çıkabilecek ihtimallerin tahmin edilmesi gibi konularda dijital ikiz kullanılabilmektedir. Bu yöntemle toplanan verilerle bir şehrin bile çok gerçekçi dijital ikizi artık kolaylıkla yapılabilmektedir (Bagheri vd., 2015: 1625).

Özetle siber ve fiziksel alanları kapsayan her türlü modelleme, iletişim, hesaplama, güvenlik ve kontrolle ilgili olan CPS teorisi sayesinde yeni paradigmalar, kavramlar ve platformlar geliştirilebilmektedir. CPS'in yukarıda anlatılan ilerlemeleriyle birlikte hala gelişiminin ilk aşamasında olduğunun belirtilmesi (Xiong vd., 2105: 323), sonraki aşamalara dair ilgi uyandırmaktadır. Bu da Toplum 5.0'ın gereklerinden olan esneklik, otomasyon, veri üretimi, depolanması, işlenmesi ve kişiler ile kurumlar arasında sorunsuz bir bağlantı kurularak optimizasyonların sağlanması için gerekli alt yapının CPS ile elde edilebileceği anlamına gelmektedir.

\subsection{Yeni Nesil Yapay Zekâ: CPSS (Cyber- Physical- Social- Systems)}

Her ne kadar CPS karmaşık sistemlere dair ar-ge çalışmalarında verimli sonuçlar verse de enerji, ulaşım, askeri, imalat, yenilikçi sosyal Sayfa | 1509 yönetim vb. alanlarla sınırlı kalmaktadır. Ancak bu teknoloji, insanlar gibi karmaşık organizasyonlardan ve toplumlardan gelen çeşitli, belirsiz ve büyük hacimli verilerin işlenmesinde yetersiz kalmaktadır. Bu durum kesin nicel sonuçlara ulaşabilmede CPS'in tüm çalışma biçimlerine uyum sağlayamayabileceği ya da birtakım şartlarda eksik kalabileceği anlamına gelmektedir. Bu nedenle sosyal faktörlerin geri bildirimine açık, sosyal davranışların kaydedildiği, analiz edilebildiği, internet ve büyük veri teknolojilerine dayanalı bir karmaşık sistemler aracına intiyaç duyulmuştur. Buradan yola çıkılarak geleneksel matematiksel modelleme yöntemine sahip CPS'lere, insanların davranışlarını ve zihni durumları ile hava durumu, çevre vb. sistemlerin modellenmesine yardımcı olabilecek yeni gözelikler eklenerek CPSS'ler geliştirilmiştir (Xiong vd., 2015: 323). Böylece fiziksel bir sistem, insanları içeren sosyal bir sistem ve her ikisini birbirine bağlayan siber sistemlerin birbirini anlayabilmesi, etkileşimleriyle birbirlerini geliştirebilmesi ve etkin, kontrollü, güvenilir ve verimli şekilde birlikte çalışabilmesi sağlanmıştır.

İnsanın döngüye katılmasıyla mekansal-zamansal, davranışsal ve kolektif kamu görüşleri dahil olmak üzere üretilen verilerin tipik karmaşık sistemlerin temel özelliklerinden biri haline gelmesi aynı zamanda CPS'ten CPSS seviyesine doğru bir paradigma kaymasını temsil etmektedir. Burada 
fiziksel ve siber olanın birleştirilmesinden öte işlemlerinde ve yönlendirilmiş görev ortamındaki etkileşimlerinde daha sıkı bir entegrasyon bulunmaktadır. Bu entegrasyon, siber alanda deneyimlenen sosyal etkileşimleri ve buna bağlı olarak gelişen davranış şekillerini, fiziksel alan seviyesinde gerçek bir alana dönüştürmektedir. Burada sosyal yaşam alanı ağ içinde genişletilerek mobil uygulamaların ve sosyal medya aracılığıyla sosyal dinamiklerin etkin olduğu yeni bir alan açılmaktadır (Wang vd., 2016: 379- 380).

Şekil 4: Bir CPSS'in ana unsurları (De vd., 2017)

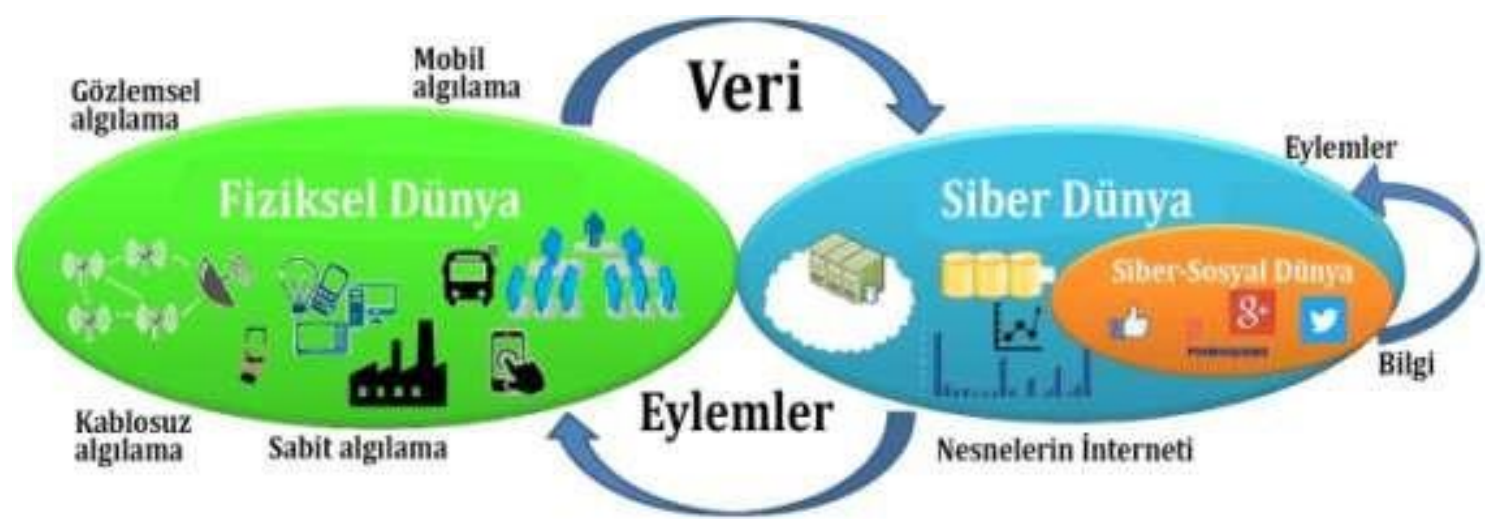

Bir CPSS'in geliştirilebilmesi için CPS'teki iki katman ile sosyal katmanın birbiriyle etkileşime girmesinin gerekliliği Şekil 4'te Sayfa| 1510 gösterilmektedir. Burada Fiziksel dünyadan alınan veriler siber dünyada işlenmekte, siber alandaki sosyal verilerle birleştirilerek çıkarılan yeni eylemsel sonuçlar tekrar fiziksel alana iletilmektedir. Böylece sonsuz biçimde sürüp giden bu döngüsel sistemde sosyal faktörün ana rolü oynaması sorunludur. Aksi takdirde CPSS özelliğini kaybetmektedir. Çünkü CPSS teknolojisi, bir sosyal boyut etrafında inşa edilmektedir. Diğer eklentiler onun eylemleri etrafında konumlandırılmaktadır (Sabou ve Musil, 2018: 28). Kategorik olarak ifade edilmek istendiğinde insanlardan toplanan sosyal veriler kullanıcının ilgi alanları, tercihleri, bilgileri ve davranışlarını kapsarken fiziksel veriler ise kaza raporları, trafik durumu, hava koşulları vb. bilgileri içermektedir. Bir CPSS'te sosyal sensöre dönüşen kullanıcılar hem sisteme sosyal verileri sağlamakta hem de sistemin önerilerine tepki vererek onu beslemektedirler. Burada bir konuda daha verimli karar almak isteyen kullanıcılar benzer ilgilere sahip kullanıcıların davranışlarından faydalanmaktadır (Sabou ve Musil, 2018: 37-38). Bütün bu özellikleriyle hesaplama, depolama, ağ oluşturma vb. işlemleri eşzamanlı yapabilen bir CPSS, kaynakların optimum şekilde kullanılması ve kullanıcıların taleplerinin zamanında karşılanması sürecinde CPS'in yerini almaya başlamıştır (Islam vd., 2017: 1). Farkın daha iyi anlaşılabilmesi açısından şu örnek verilebilir: Sensör hesaplarına dayalı olarak yorgun sürücü tespiti yapan CPS 
teknolojisinde insanın sistemle gerçek bir etkileşimi ve aktif biçimde bir rolü yoktur. Fakat görme engellilere yardımcı olan bir sistemde kullanıcı, sosyal medya üzerinden veri elde edebilmekte ve işlem sırasında CPSS'le direkt etkileşime girebilmektedir. Kullanıcı sonuçlardan yararlanıp hem hedefe ulaşırken sisteme veri de sağlamaktadırlar (Sabou ve Musil, 2018: 31).

Sosyal veriler sadece kişisel bilgisayarlardan değil artık cep telefonları, tabletler, akıllı cihazlar yoluyla ve her yerde ağa bağlı kalınabilmesi gerçeğiyle kolaylıkla sağlanabilmektedir. Öyleyse bir CPSS'te siber-fiziksel alan ve insanın bir arada olması insanın sosyo- psikolojik davranışlarının kaynağı olan zihinsel alana da ulaşılabildiği söylenebilir. Çünkü bu tür oluşan veriler sadece siber uzay ve fiziksel mekân ile ilgili değil, aynı zamanda insanın bilgisi, zihinsel yetenekleri ve diğer sosyokültürel unsurlarından oluşmaktadır. Bu da siber uzaydan gelen bilgilerin, fiziksel alan ve zihinsel alanla etkileşime girmesiyle kişisel ve sosyal kullanımı konusunda CPSS'e hesaplama kolaylığı sunmaktadır. Böylece bir işbirlikçi zekâ olarak insanların veri sağlama, işleme ve veri çıktılarına göre karar almaları mümkün hale gelmektedir. Sonuçta bütün bu bileşenler sayesinde bir CPSS'te insanlar sistemlerin zekâsına, durum farkındalığına, sistem ölçeklenebilirliğine vb. katkıda bulunurken kontrol ve yönetim yeteneklerini de arttırabilmektedirler (Smirnov vd., 2015: 124). Öte yandan Sayfa | 1511 siber alanda organize olan iletişim temelinde birleşen, çeşitli veri ve hesaplamaları içeren cihazlar vasıtasıyla CPSS teknolojisi, sistemler ve insanlar arasındaki koordinasyonu sağlarken eşzamanlı karar verilebilme gibi organizasyonel bir zekâyı gerektiren çoklu danışma ve uyarlanabilir organizasyon yapısını da mümkün hale getirmektedir.

\section{CPSS Teknolojisinde Sosyal Veri Kaynakları}

Dünyanın her yerinden milyonlarca kullanıcı tek bir sosyal medya platformu üzerinden siber uzayda toplanarak büyük bir bilgi ve enerjiyi reel alanlarda birleştirebilmektedirler. Ocak 2021 verilerine göre dünya çapında 4,66 milyar aktif internet kullanıcısından \%92,6'sı (4,32 milyar), internete mobil cihazlar üzerinden erişmektedir. Dünya çapında aktif küresel sosyal medya nüfusu ise 4,2 milyar civarında, aktif mobil sosyal medya nüfusunun ise 4,15 milyar olarak kaydedilmesi (Tankovska, 2021), internetin ve sosyal medyanın şimdiden dünya nüfusunun yarısından fazlasını oluşturduğunu göstermektedir. Sosyal ağlarının, olabilecek gizlilik gibi çeşitli kısıtlamalara takılmadan resmi haber kanallarından önce ve daha kolay bir şekilde verilere ulaşması, bu kaynakların tercih edilmesinin nedeni sayılabilir. Bu durum sosyal ağlardan kullanıcının tercihlerine, katılacağı etkinliklere ve diğer verilere erişmeyi mümkün kılmaktadır. 
Karar verme veya davranış tanıma gibi işlemleri gerçekleştirmek için büyük miktarda veriyle uğraşmak zorunda olan CPSS'lerin en iyi sonuçları sağlaması için verilerin nereden toplandığının bilinmesi gerekmektedir. Bu açıdan bakıldığında,

a. Trafik bilgisi, hava durumu vb. hakkındaki ortam durumu

b. Posta kutusu verileri gibi kullanıcının duygusal ve fizyolojik durumu

c. Hizmet sağlayıcıların, kullanıcılardan aldığı hizmet derecelendirmeleri

d. Kullanıcının kontrol, onaylama, tweetler ve kabul edilen sosyal etkinlikleri

e. Tahliye süreçleri, montaj hattındaki işçiler ve yayalar hakkındaki fiziksel davranışlar ve faaliyetler

f. Çağrı merkezlerine yapılan şikâyet ve taleplerle araç ve yolcu kayıtları, yol bilgileri, sürüş hızları gibi ölçülebilir bilgiler (Sabou ve Musil, 2018: 41).

Verileri toplayıp işlenmesine yardımcı olan sosyo-teknik sistemlerin örnekleri arasında Facebook, Twitter, Yelp, YouTube gibi paylaşım sistemleri ve Amazon Mechanical Turk, Crowd Flower gibi kitle kaynak sistemleri sayılabilir. Ayrıca birçok CPSS'in daha geniş bilgi edinmek, etkinliklerini artırması, yeni stratejiler geliştirmek amacıyla farklı veri ontolojilerini de Sayfa | 1512 kullanabilmektedir. Bu doğrultuda, anlamsal webin, heterojen nesnelerin aynı anlama gelmesine izin veren anahtar teknoloji olarak ontoloji ve arayüz gibi akıllı ajan teknolojisi sayesinde insan olmayan kaynaklarla iletişim sağlanarak sonuca varılabilmektedir (Smirnov vd., 2015: 124). Bir CPSS'te veri toplama ve birleştirme süreci olarak tanımlanan sosyal algılama süreci şu şekilde işlemektedir:

a. Fiziksel sensör ortam verisini, uygulamalar ise sosyal verileri toplamakta

b. Bir işleme birimi verileri temizleyip aktarım için hazırlamakta

c. Aktarım birimi verileri buluta göndermekte

d. Yardımcı birimlerle veriler geri çağrılmaktadır (Xiong vd., 2015: 327).

Sonuç olarak ilkin 1990'larda başladığı anlaşılan karmaşık sistem çalışmaları (Xiong vd., 2015: 323), günümüzde bilgi alanındaki siber ağlar, bilişsel alandaki zihinsel öğeler ve sosyal alandaki sosyal ağlar iş birliğiyle insan zihniyetinden fiziksel sistemlere kadar bir zincirin etkili bir şekilde kontrol edebileceği bir aşamaya geldiği görülmektedir. CPSS'in multidisipliner yaklaşımla çalışılması, YZ tabanlı akıllı sistemler ve buna bağlı alanlardaki başarılı inşa ve dağıtımın yeni anahtarı olabilir. Böylece BİT'ten en iyi şekilde yararlanılmasının bir yolu olarak CPSS'in sosyal refah 
ve istikrara yönelik toplumsal yönetim, koordinasyon ve hizmetlerin düzenlenmesini sağlamada önemli rol üstlenebileceği söylenebilir. Öyleyse Endürstri 4.0'ın teknolojisi olan CPS'lerin üst versiyonu olarak CPSS teknolojisinin, Toplum 5.0 benzeri bir akıllı toplum için kullanışlı olduğu, ancak bu teknolojinin uygun bir biçimde kullanılmasını sağlayacak bir yönteme intiyaç bulunduğu sonucuna varılabilir.

\section{Sosyal Bilimlere Deney İmanı Sunan ve Toplum 5.0'ı İnşa Edebilecek Bir Yöntem Olarak ACP Yaklaşımı}

Sosyal bilimlerin bir bilim olarak kabul görülmesi için deney ve gözleme dayalı istatistiki verilere ve kesin sonuçlara dayalı olmasının gerekliliği üzerinde uzun süre durulmuştur. Mantıkçı pozitivist akımın kurucularından Comte ve J. S. Mill tarafından savunulan bu görüş, "yöntem birliği" kapsamında sosyal bilimler doğa bilimlerinin çalışma yöntemini nesnellik ölçütlerini yerine getirmesi bakımından aynılığını savunmaktadır. Bu görüşün karşısına çıkan yorumcu (hermenuetik) yaklaşıma göre ise hem konu ve içerik hem de yöntem ve elde ettiği bilginin niteliği bakımından doğa bilimlerinden oldukça farklı olması dolayısıyla sosyal bilimler, doğa bilimleri mantığına göre ele alınamaz. Çünkü sosyal bilimlerinin konusunu teşkil eden kültür, ideoloji, kurallar, inançlar ve değerler sabit ve değişmez değildirler. Öte yandan, karmaşık ilişkiler ağı içinde sosyal bilimlerin görevi Sayfa | 1513 insan davranışlarının nesnel yasalarını ortaya çıkarmak değil, insan davranışını ait olduğu gelenek ve öznel değerler bağlamında anlamak ve kendi rasyonalitesini kavramaktır. Bunun için sosyal bilimci kimi kez parçayı veya bireysel olayı anlamak için genel olguya, genel olguyu veya teoriyi kanıtlamak için de tek tek olaylara veya parçalara başvurur (Yılmaz ve Yazıcı, 2017: 59-63).

Sosyal bilimler alanında deney ve gözlem yapabilmenin sorunlu oluşundan kaynaklanan bu tartışmada günümüzde bir aşamaya gelindiği söylenebilir. Hem doğa hem de toplumsal yaşama ait bilginin oluşumunda insan belirleyici olması nedeniyle bilimin, kesinliği ve nesnelliği ifade eden sembollerle değil olası sonuçlarla işlemesinin gerekliliği büyük ölçüde kabul görmektedir. Ancak deney ve gözlem bilimdeki önemini hala korumaktadır. $\mathrm{Bu}$ nedenle "Artificial society - computational experiment - parallel execution" şeklinde kavramlaştırılan ve ACP olarak kısaltılan yaklaşım, söz konusu yorumsamacı görüşü desteklemekle birlikte doğa bilimlerinin bilimsellik anlayışlarına uygun biçimde deneysel ve gözleme dayalı bir bilim özelliğini de sosyal bilimlere eklemektedir. Bu başlık altında bu yaklaşımın işleyiş biçimi tahlil edilmektedir. ACP yaklaşımına Türkçe kaynaklarda rastlanmamasından dolayı İngilizce metinlerden yararlanılarak bu çalışma 
yapılmıştır. Bu nedenle ilk kez bu çalışmada Türkçe literatür için çevrilen kavramın yapay toplum-bilişimsel deney- paralel yürütme şeklinde ifadesi uygun görülmüştür. Ancak dünya literatürüyle uyumu sürdürmek için bu çalışmada, İngilizce kısaltma olan ACP ifadesi kullanılmaktadır.

\section{Sosyal Hesaplamanın Tarihi Arka Planı}

A-C-P'nin her birinin ayrı birer bilimsel alan olduğu göz önüne alındığında (Wang, 2007: 65) tarihi arka planın belirlenmesi için her bölüme ayrı ayrı bakılması gerekmektedir. Bu nedenle ilk olarak $A^{\prime}$ nın temsil ettiği bilgisayarların, sosyal laboratuarlar olarak ele alınabileceğini ifade eden yapay toplum tartışmalarının ilk olarak Epstein ve Axtell tarafından ortaya atıldığı görülmektedir (Epstein ve Axtell, 1996: 2). Bu şekilde sosyal hesaplama problemlerindeki çeşitli faktörlerin değerlendirilip ve niceliksel olarak analiz edebileceğini savunan yazarlar, oluşturulan yapay bir sistemle karşılaştırma, değerlendirme ve etkileşim yoluyla karmaşık sosyal sistemlerde kontrol ve yönetim mekanizması sağlanabildiğini ifade etmektedirler. Böylece gerçek sistemlerde gerçek zamanlı iyileştirmeler yapılarak doğru kontrol ve yönetim yapılabilmektedir.

Sacks vd. tarafından yapılan çalışmada da C'nin temsil ettiği bilişimsel deneylerle ilgili ilk izlere rastlanmaktadır. Yazarlar, istatistiğin, fiziksel Sayfa| 1514 deneyler için bile yetersiz olduğu düşünenlere karşı bilişimsel deneylere uyguladıkları rastlantısal modellerle, gözlemin yapılamadığı alanlardaki yanıtların belirsizliğini ölçerek tasarım ve analiz için uygun bir çerçeve sağlamışlardır. Böylece bilinmeyen, deterministik bir bilgisayar modeline, istatistiksel bir yaklaşımla ilginç ve okunabilir bir açıklama sunabilmişlerdir (Sacks vd., 1989: 423). Kydland ve Prescott ise ekonomi alanında geliştirdikleri modelde bilişimsel deneyi kullanmışlardır. Deneye araştırmacının öncelikle iyi tanımlanmış nicel bir soru sorarak başladığını belirtene yazarlar, daha sonra ulusal bir ekonominin bilgisayar temsili olan model bir ekonomi oluşturmak için hem teori hem de istatistiği kullanmışlardır (Kydland ve Prescott, 1996).

Microsoft tarafından yapılan çalışmada (Microsoft, 2007), P'i temsil eden paralel yürütme ile ilgili olarak bu kavramın, uygulamaların paralel yürütülmesi, sistem mimarisi ve yazılım sorunları ile ilgilenen bilgisayar disiplini ile ilgili olduğu anlatılmaktadır. 1950'ı yılların ortalarında eşzamanlı bilgisayarlı hesaplamalara kadar dayandırılabilen bu kavram, terimsel kullanımlarda farklılık göstermesi nedeniyle kökeni ile ilgili tam bir tarihi tespit yapılamamaktadır. Bu nedenle onlarca yıldır aktif bir araştırma ve uygulama alanı olduğu anlatılan paralel hesaplamanın, esas olarak yüksek performanslı bilişimin odak noktası olduğu, ancak yarı iletken endüstrinin 
çok çekirdekli işlemcilere geçişiyle birlikte yaygın bilgi işlem paradigması olarak görüldüğü anlaşılmaktadır (Adjepon-Yamoah, 2012: 8-9).

Temel olarak bu şekilde anlatılabilen ACP'nin tarihi arka planına bağlı kalarak, fakat farklı felsefi dayanak noktaları da alarak yeni bir bilim alanının ilk açıklamasını yapan Wang, bilişimsel bir sosyal hesaplama yöntemini sunmuştur (Wang, 2007: 65). Bu bilimin kökenlerini 1945-1950'lerdeki Vannevar Bush'un Memex'ine2, Engelbart'ın psikoloji ve örgütsel gelişimi bilgisayar teknolojisindeki gelişmelerle bütünleştirme vizyonuna ${ }^{3}$ ve Licklider'ın ${ }^{4}$ bilgisayarları makine değil, iletişim cihazları olarak algıladığı çalışmalarına dayandırmaktadır. Sosyal bilişim araştırmalarını etkileyen bu öncülerin ürünleri, bilgi teknolojlerindeki uygulamaların ilk prototipleri olarak değerlendirmek mümkündür (Wang, 2007: 65). Bunların dışında Popper'ın üç dünya teorisi de Wang'ın çalışmasını destekler niteliktedir. Buradaki fiziksel (birinci dünya), zihinsel (ikinci dünya) ve yapay (üçüncü dünya) evren (İyigüngör, 2015: 51), internetten önceki fiziksel ve zihinsel dünyaları içeren fakat sadece fiziksel alanda somutlaşmış yaşam alanıyla uyumludur. Bu alan günümüzde internet, nesnelerin interneti, bulut bilişim ve büyük verinin varlığıyla yapay dünyayı da içine alacak şekilde genişlemiştir. Yani ağ ve bilgi teknolojilerinin gelişmesi nedeniyle siber uzay, fiziksel alanla sorunsuz bir şekilde bağlantılı hale gelişmiştir. Böylece Sayfa | 1515 fiziksel ve sosyal alanın birleştiği yapay siber dünya, felsefi soyutlamadan gündelik uygulamalara dönüştürülmüştür (Wang vd., 2016: 380). Bu genişleme ile daha da karmaşıklaşan sosyal sistemlerle ilgili çalışmalar için yeni bir yönteme intiyaç duyduğu açıktır.

Bilginin ışık hızıyla yayıldığı ve dünyanın her köşesine ulaştığı günümüzde sosyal bilişim için ACP yaklaşımının mantıksal temeli şu şekilde açıklanmaktadır:

Webe bağlanan herhangi bir kişi güçlü bir hükümetle eşit veya hatta daha büyük bir sese sahip olabilmektedir. Kullanıcılar bu imkânı iyiye ya da kötüye kullanabilmektedirler... Bu yeni bilim, gerçek zamanlı dinamikleri, kapalı döngü geri bildirimi ve yürütülebilir karar desteğini arkasına alarak istenmeyen durumlarla başa çıkabilmenin bir yöntemidir (Wang, 2007: 65).

\footnotetext{
${ }^{2}$ Tüm kitapların, kayıtların ve iletişimlerin sıkıştırıp saklanabildiği, aşırı hız ve esneklikle danışılabileceği öngörülen mekanize edilmiş bir cihaz (wikipedia.org, 2020).

3 Douglas Engelbart, hypertext, bağlantılı bilgisayarlar ve bilgisayar arabirimlerinin ilk örneklerini geliştirmiştir (wikipedia.org, 2021).

${ }^{4}$ Modern tarzda etkileşimli hesaplamayı ve bunun her tür faaliyete uygulanmasını öngören ilk kişilerden biri olduğu gibi dünya çapında bir bilgisayar ağının erken vizyonuna sahip bir internet öncüsü olarak bilinmektedir (wikipedia.org, 2021).
} 
Anlaşılan Wang bu bilimi sosyal alanlarda hesaplamaya dair bir kontrol yönetim biçimini açıklamaktadır. Yeni BİT'le birlikte sosyal bilimler alanında paradigma değişimine ihtiyaç duyulması da bu çalışmanın gerekliliklerinden sayılabilir. Bu nedenle daha önce mühendislik problemlerin çözümünde de kullanılan modelleme, analiz ve kontrol aşamaları sosyal bilimlere de uygulanması, tekrarlanabilir deneylerle aktif testler ve değerlendirmeler yapılabilmektedir. Sübjektif, kontrol edilemeyen ve gözlemlenemeyen faktörlerin fazlalığıyla zorlaşan analitik muhakemeler için ACP'le çözüm sunulabilmektedir. Böylece genellikle pasif düzeyde kalan gözlemler ve istatistiksel yöntemlerin zorunluluğu ortadan kalkmaktadır. Bu yöntem Wang'dan sonra birçok bilişim mühendisi ve sosyal bilişimci tarafından test edilmiştir (Xie, 2010; Adjepon-Yamoah, 2012; Hu vd., 2014 vs.; Xiong vd., 2015; Wang vd., 2016-2018; Pereira vd., 2020 vb.).

\section{ACP Yaklaşımının Fonksiyonu}

ACP yaklaşımının esas fonksiyonu yapay sistemlerin modellenmesinin yapılarak bireysel, örgütsel ve sosyal davranışların hesaplama modellerinin ortaya çıkarılmasıdır. Bilgisayar ortamında yapay bir benzerinin (siber ikiz) yapılmasıyla toplumlar hesaplamaya uygun hale getirilmektedir. Çok etmenli simülasyona dayanan bilişimsel deneylerde ise çeşitli mekanizma tasarımıyla ortaya çıkan davranışın gözlemlenmesi ve incelenmesiyle sosyal öğrenme ve davranışın çeşitli özellikleri ve örgütsel ilkeleri ortaya çıkarılmaktadır (Xiong vd., 2105: 325). Bunun yanı sıra bilişimsel deneyler; politikalarının nicel etkilerinin tahmini, ticaretin serbestleştirilmesi, vergi sistemindeki değişiklikler, refah sonuçlarının ölçülmesi, farklı şok türlerinin neden olduğu iş döngüsü dalgalanmalarının büyüklüğü ve niteliğinin ölçülmesinde kullanılabilmektedir. Bilişimsel deney ister teori kullanımı ister teori geliştirme ve test etme ile ilgili olsun, kantitatif ekonomi teorisinin bir aracı olarak görülebilir (Kydland ve Prescott, 1996). Son olarak paralel yürütme alanında gerçek dünyadaki fiziksel-sosyal sistemin ve bunun yapay sistemlerdeki sanal karşılığının birlikte evrimini incelenmektedir. Burada sürekli geri bildirimle model iyileştirmeleri sağlanarak gerçek dünya etkileyicileri ile sistemler arasında politika değerlendirmesi için bağlantı kurulmakta, yeni uygulama ve uyarlamalar geliştirilmektedir. Paralel yürütme temel olarak yapay sistemlerdeki ajanların diğer ajanlarla etkileşimini ve bilgi alışverişi protokol tasarımı; fiziksel-sosyal ve yapay sistemler arasındaki bilgi ve kontrol sinyali alışverişinin biçimlendirilmesi; gerçek ve yapay sistemler arasındaki etkileşimlerde sistem optimizasyonu ve tasarımı; paralel sistem için siparişe dayalı optimizasyon yöntemleri vb. ile ilgilenmektedir (Xiong vd., 2015). Geniş bir araştırma alanı olduğu anlaşılan ACP yaklaşımının işleyiş biçimine kısaca bakıldığında yazılım 
programları aracılığıyla gerçek dünyadaki toplumsal sistemlerin yapay modellenmesinin A bölümünde gerçekleştirilmektedir. Burada bir veya daha fazla yapay toplumsal sistem kurulabilmektedir. Gerçek ve yapay toplumsal sistemlerdeki davranışlar, mekanizmalar ve stratejiler $C$ bölümünde çeşitlendirilmiş bilişimsel deneyler aracılığıyla değerlendirilmektedir. Bu deneyler, "eğer öyleyse ne olurdu" kurallarına dayalı olarak önceden tanımlanmıştır. Çok sayıda bilişimsel deneyle tespit edilen en uygun çözüm kontrol-yönetim için insan ve bilgisayar eş yönetimini ifade eden $P$ kısmındaki paralel (eşzamanlı) yürütmeyle gerçek sistemlere yansıtılmaktadır. Geri bildirimlerle sürekli tekrar edilen bu çalışmalar sonucunda gerçek toplumsal sistemin en iyi yapay benzerlerine ulaşılabilmektedir (Wang vd. 2018: 6). ACP tabanlı paralel kontrol ve yönetim CPSS katmalarına uygun olarak 4 aşamada gerçekleşmektedir:

a. Program bileşenleri için önceden tanımlanmış temel bileşenler seviyesi

b. Kontrol ve yönetim modelleri model algoritmalar kitaplığı ve uzman bilgi tabanı olarak ifade edilen çekirdek seviye olan veri ve bilgi seviyesi

c. Deney tasarımı, uygulaması ve analizi ile kontrol ve yönetim programlarının değerlendirme ve karar desteğini sağlayabilen Sayfa | 1517 fonksiyon gerçekleştirme modülü olan bilişimsel deney seviyesi

d. CPSS bilgi alışverişi ve geri bildiriminin kontrolünü ve yönetimini gerçekleştirebilen, işlev ekranı ve kullanıcı arayüzü için bir katman olan paralel yürütme seviyesi (Xiong vd., 2015).

Şekil 5: ACP tabanlı paralel zekânın (Wang vd., 2016: 389)

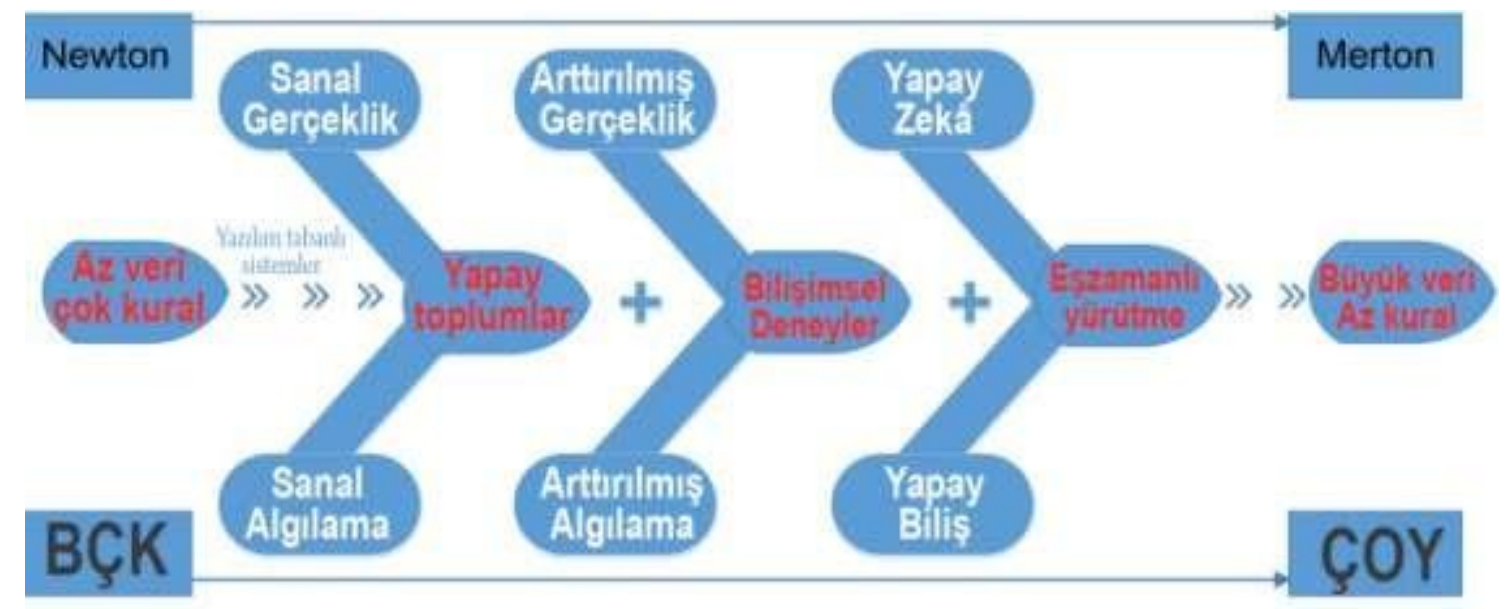

Şekil 5'te paralel zekânın tanımlayıcı özelliği olduğu paralel toplum veya Toplum 5.0'da temel belirsizlik, çeşitlilik ve karmaşıklık (BÇK) zorlukları sanal yapay sistem kullanılarak basitleştirilmektedirler. Böylece 
elde edilebilen çevik, odaklanmış ve yakınsak (ÇOY) yönetim ile karmaşık toplumsal sistemlerin kontrolü sağlanabildiği gösterilmektedir. Hem çevrimiçi platformlar hem de çevrimdışı topluluklara yönelik olan modern BİT tabanlı akıllı yönetim ve kontrol sayesinde toplum üyeleri her zaman her yerde ara yüzler sayesinde etkileşime girebilmektedir. Buradan paylaşılan bilgi ve tecrübelerle eşit haklara sahip bir toplumsal yapı inşa etmek mümkünken yönetim ve rehberlik için de adil bir sosyal yapı inşa edilebilir. Bu yöntem siviller ve hükümet arasında doğrudan bir etkileşimin sağlanmasını, insanların kamu işlerine katılımını kolaylaştırması da sağlamakta, böylece çeşitlendirilmiş, etkileşimli ve hizmet odaklı bir sosyal harita sağlanabilmektedir. Görünen o ki ACP yaklaşımının işleyiş biçimi sayesinde ulaşılabilen gerçek fiziksel toplum ile sanal yapay toplumlar arasındaki paralel zekânın gerçekleştirilmesi zaman, insan, kaynaklar, senaryolar ve organizasyonların sistem unsurlarının bir araya getirilmesiyle akıllı toplumların inşasını mümkün kılarak Toplum 5.0'ın da gerçekleşmesini sağlayabilir (Wang vd., 2016: 389).

\section{ACP Yaklaşımıyla İlgili Bazı Uygulama Örnekleri}

ACP yaklaşımıyla hazırlanan CPSS uygulama örneklerinin toplumsal yönetim ve kontrol kabiliyetlerini geliştirerek Toplum 5.0 gibi akıllı toplumları inşa etmeye yardımcı bir araç olup olmadığının daha net Sayfa | 1518 anlaşılması bakamından CPSS taslaklarının amacı ve işleyiş biçimleri aşağıda açıklanmaktadır.

\section{a. Kişiselleştirilmiş Üretime Yönelik CPSS Taslağı}

Sosyal sensörler ve CPS düğümlerinin kişiselleştirilmiş üretimin gerçekleştirilmesi amacıyla Ding ve Jiang tarafından birleştirilerek, gelecekteki kitlesel kişiselleştirilmiş üretim için anlık ve birebir çalışmaya uygun bir CPSS çalışılmıştır. Şekil 6'da görülen taslak unsurların gösterildiği şekilde ilişkilendirilmesiyle kişiselleştirilmiş üretime yönelik iş birliği amacıyla müşteriler, kuruluşlar ve diğer paydaşlar, işletmelere ve onların CPS düğümlerine bağlanabilmektedir. 
Şekil 6: Kişiselleştirilmiş üretim CPSS (Ding ve Jiang, 2016)

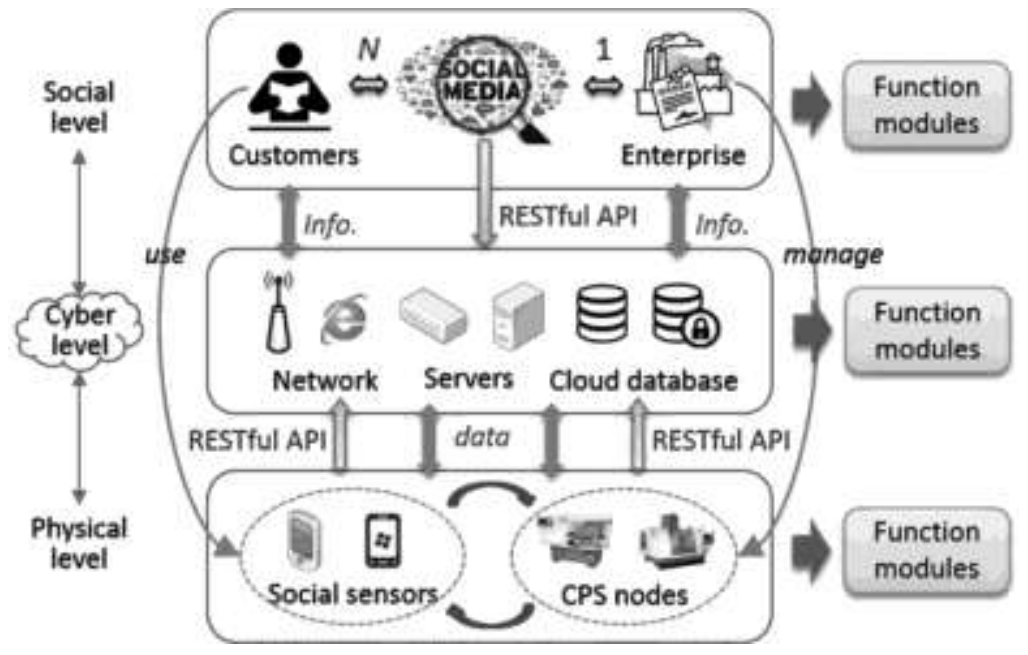

Burada sosyal sensörler, sosyal medya ile diğer uygulamaları entegre etmek için bir uygulama ara yüzü (API) aracılığıyla CPSS'in ilk katmanı olan fiziksel katmanı geliştirilmiştir. İkinci katman ise sunucuların yer aldığı fiziksel ve sosyal katmanı birbirine bağlamaktadır. Bu sunucular aynı zamanda, sosyal ve endüstriyel büyük verilerin toplanabilmesiyle müşterilere ve işletmelere birlikte çalışma zemini hazırlamakta ve verileri Sayfa | 1519 bulut veri tabanına ulaştırmaktadır. Üçüncü katman ise müşteriler ve işletmeler arasındaki etkileşimi kolaylaştıran 3. taraf API aracılığıyla çeşitli sosyal medyadan oluşan sosyal katmandır. Burada sosyal veriler, sosyal sensörler tarafından toplanır ve ön işlemden geçirilerek buluta yönlendirilir. Sosyal imalat ortamında kişiselleştirilmiş üretim için müşteriler, takipçiler ve tedarikçiler de birbirleriyle etkileşim kurması için CPSS platformuna katılmaktadır. Ardından ürün geliştirme aşamasına geçilince girişimci tarafından, sanal sosyal toplulukta belirli işlevlere sahip yeni bir ürün geliştireceği ilan edilir. Çevrimiçi sosyal medyada etkileşimlerini başlatan bu olayla takipçiler, ürün işlevlerini tartışmak, zaman ve konum endişelerini veya fikirlerini açıklamak için etkileşime girmektedirler. Bu arada sosyal sensörlere yüklenen mobil uygulamalar etkileşim olaylarını ve sosyal bağlamları belli aralıklarla taramakta ve bunları biçimlendirilmiş sosyal verilere dönüştürmektedir. Geliştirilen bir model, farklı bölgelerdeki gizli müşteri eğilimlerinin tahmini ve müşteri gereksinimleri ile ürün işlevleri arasındaki eşleştirme ilişkilerini bulmak için sosyal verileri sürekli kullanarak yeni sonuçlar çıkarmakta ve müşterilerle paylaşmaktadır. Son aşamada müşteri ve işletme arasında kurulan bu iş birliği ile üretim dinamik olarak iyileştirilirken gerçek zamanlı olarak da kontrol edilmektedir. Böylece işletme elde ettiği anlık sosyal ve endüstriyel veriye dayanarak üretim 
planlarında ayarlamalar yapabilmektedir. Dahası, kurumsal müşteriler geri bildirim alınabilmesi yeni ürünleri piyasaya sürmek için genişletilmiş pazar intiyaçlarını bulmada da kullanılabilmektedir (Ding ve Jiang, 2016: 370).

\section{b. Akıllı Toplantı Odası CPSS Taslağı}

CPSS kaynaklarının birlikte çalışabilirliğini test etmek için ontolojilerden faydalanılmasına yönelik Smirnov vd. tarafından anlamsal webin ajan6 olarak kullanıldığı bir taslak hazırlamışlardır. Buna göre insan ve insan dışı kaynakları içeren bir CPSS'te özerk akıllı ajanlardan faydalanılarak insan olmayan kaynaklarla iletişim sağlanmaktadır. Farklı veri ontolojileri ile ajan iş birliğinin sağlanmasına çalışılan yöntemde iletişim türü eşzamanlı veya eş zamansız olabilmektedir. Çevrimiçi topluluklarda kabul edilen normlara uygun olarak hazırlanan bir protokole göre ajan organizasyonunun temel iş birliği ilkeleri de belirlenmektedir. Bu protokol çerçevesinde:

1. Ajanlar, genel sistem faydasına en iyi katkı için iş birliği yapmalıdır.

2. Ana hedef, görev performansını tamamlamaktır, kar elde etmek değildir.

3. Aracısız etkileşimdeolan ajanlar merkezi olmayan bir toplulukta çalışır

4. Ajanlar ortak terimler ontolojini kullanırlar.

5. Ajanlar aynı sistemde çalıştıkları için birbirlerine tamamen güvenebilirler.

6. Ajanların iletişimi katıldığı çevrimiçi topluluk normlarına uygundur.

Şekil 7: Akıllı toplantı odası CPSS taslağı (Smirnov vd., 2015: 131)

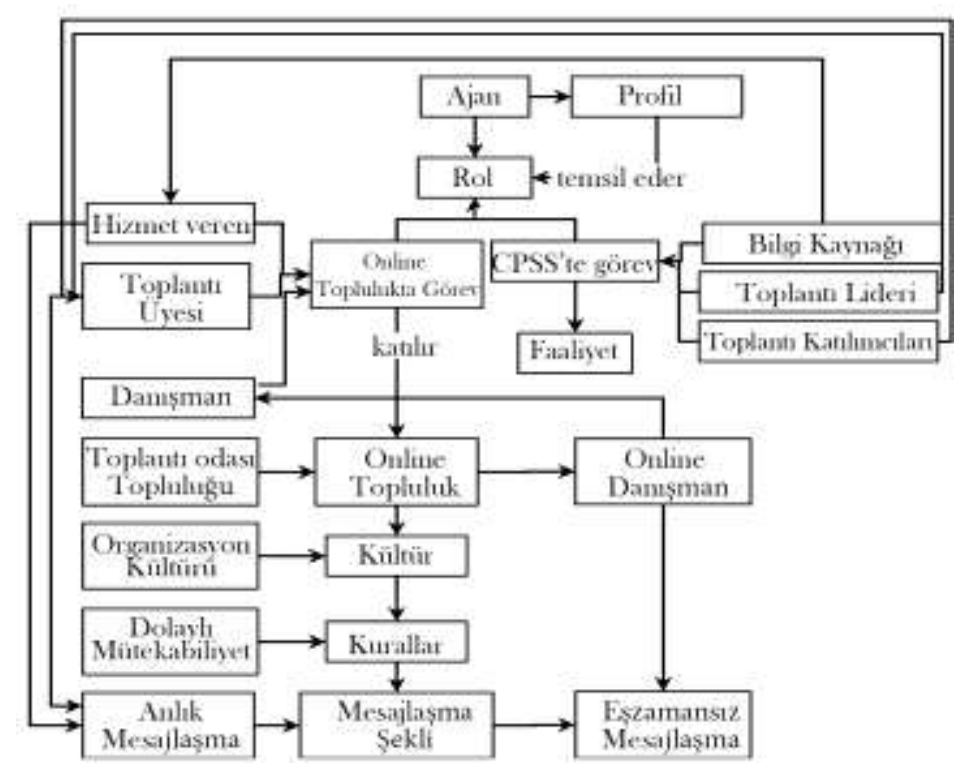


Bu kurallar göre Şekil 7'de Smirnov vd. tarafından çalışılan akıllı toplantı odası CPSS'inde bir toplantı odasında, iş planı için kullanılan elektronik tablolar ve gerçek zamanlı çeşitli veriler kurumsal bilgi kaynaklarını yetersizliğinde devreye girmektedir. Amaç kurumsal kaynaklarla elde edilemeyen verilerin kurum dışından yardım alınarak elde edilebilmesidir. Burada ajanlar devreye girerek bilgi kaynağı rolünü yerine getirmektedirler. Ajanlar, toplantı odası dışında gerekli verileri sağlayabilmek için toplantı üyesi olmayan çevrimiçi bir danışmana başvurmaktadırlar. Bu danışman, toplantı katılımcılarına verilerin nerede bulunabileceğine dair bir mesaj göndermektedir. İlgili veriler örneğin, yapılan telefon görüşmesinden sonra kullanılabilir hale gelmektedir. Böylece ajan ontolojisi, ajan rolü ve organizasyon kültürüne bağlamında ajan iletişimi gerçekleşmiş olmaktadır (Smirnov vd., 2015: 124-132).

Şekil 8: Akıllı seyahat CPSS taslağı (Smirnov vd., 2015: 134)

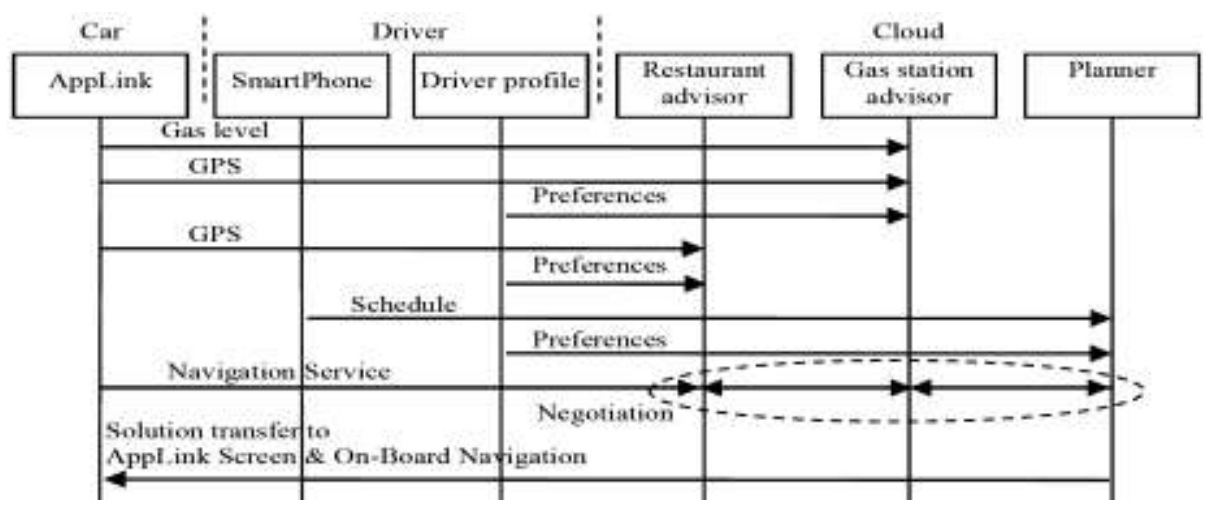

Sayfa | 1521

\section{c. Akıllı Seyehat CPSS Taslağı}

Akıllı ajan ontolojisini, akıllı seyahat CPSS'i için de uygulayan Smirnov vd., burada yakıt alacak birinin aynı zamanda düzgün bir restoranda gitmek istediğinde bir CPSS'ten nasıl yararlanabileceği gösterilmektedir. Şekil 8'de gösterilen taslakta ajanlar, bir restoranın yakınında bulunan ve müşterilerinden iyi bir geri dönüş alan bir yeri veya bu kişinin tercih ettiği markaya ait bir benzin istasyonunu arayıp bulabilmektedirler. Bu tasarımda sürücü rolünü yerine getiren ajan, bir restoranda gitmek ve yakıt ikmali yapmak istediğinde sürücü ajanını ve kaynaklarını temsil eden ajanların yanı sıra, müzakereye üç ajan daha katılmaktadır: Restoran danışmanı, benzin istasyonu danışmanı ve planlamacıdan oluşan bu üç ajanın her birine sürücü için önerilerinin yararlılık derecesini hesaplayan belirli işlevler atanmıştır. Bu aşamada benzin istasyonu danışmanlarından alınan verilerle restoran danışmanından alınan veriler karşılaştırılmaktadır. Planlayıcı tarafından ise sürücünün akıllı telefonundan alınan sürücü tercihlerinden de faydalanılarak sürücü gereksinimlerine göre çözümler sunulmaktadır. Bu aşamada 
navigasyon sisteminin de devreye girmesiyle sürücünün AppLink ekranına seçenekler aktarılmaktadır (Smirnov vd., 2015: 134-135).

\section{d. Askeri Kontrol ve Senkronizasyon CPSS Taslağı}

Askeri kumanda ve kontrol organizasyonunun kendi kendine senkronizasyonu sağlanmak istenen CPSS'te, bir kuruluşun fiziksel kaynaklarının atanması, sensör ve etkinleştirici ağların kurulması, sosyal ağda komuta ve kontrol ilişkilerinin kurulması ve ilgili bilgilerin gerektiği gibi düzenlenip paylaşılması gibi unsurların otomatik olarak entegre edilmesi amaçlanmaktadır. Böylece operasyonel kendini organize etmesi ve uyarlanabilirliği sağlanmış olacaktır. Burada yapılacak işler sırasıyla görevlerin tanımlanması, operasyonel planlama, birimlerin ve unsurların dağıtılmış ağ ile kapsamlı entegrasyonu ve dağıtılmış organizasyonel zekâ aracılı̆ııla bir siber fiziksel organizasyonun görevlerinin hızlı bir şekilde oluşturulması olarak belirlenmiştir. Bu nedenle Şekil 9'da gösterildiği gibi bilgi ve durum analizi hizmetlerinin yardımıyla, göreve uygun bir sosyal ağ şeklinde düzenlenen komuta ve kontrol ekipleri, savaş alanının ortak operasyonel resmini almaktadır.

Şekil 9: Kontrol ve senkronizasyon CPSS taslağı (Liu vd., 2011: 94)

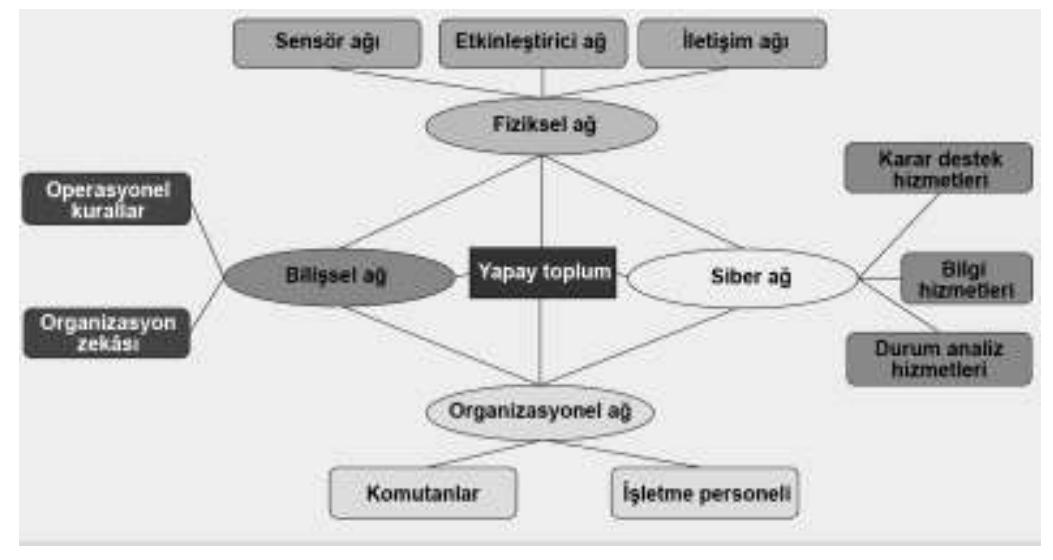

Sayfa | 1522

Daha sonra senaryo keşfi, bilişimsel deneyler ve savaş oyunları yardımıyla hedefler tanımlanmakta ve eylem planları hazırlanmaktadır. Komuta ve kontrol için fiziksel sistemler, bilgi paylaşımı, düşünme ve karar sürecinin, komuta kontrol ve koordinasyon alanlarında ilgili işlevlere entegre edilmesi, insanları ve fiziksel sistemleri gözlem, yönlendirme, karar verme ve harekete geçme döngüsünde birleştirmektedir. Böylece gerçek dünyanın durumu, insanlar ve sensör ağları tarafından durum değişkenlerinin eklendiği yapay toplumlarda izlenebilmektedir. Bilişimsel deneyler ve senaryo araştırmaları yardımıyla bu CPSS, birden çok eylem planını ve ilgili eylemlerin olası sonuçlarını sunabilmektedir. Ayrıca bir komuta ve kontrol organizasyonunun doğasındaki belirsizlik ve karmaşıklığın anlaşıması, 
birden fazla olası eğilim tahmininin yapılması ve kesin kontrol yerine kaotik kontrol ile beklenen operasyon durumunu keşfedilmesi için de bu CPSS'in kullanılabildiği belirtilmektedir. Böylece değişkenlerin duyarlılığı ve boyutları kontrol edilerek büyük felaketlerin üstesinden gelmede yardımcı olmaktadır (Liu vd., 2011: 94-95).

Şekil 10: CPSS tabanlı sosyal ulaşım taslağı (Xiong vd., 2105)

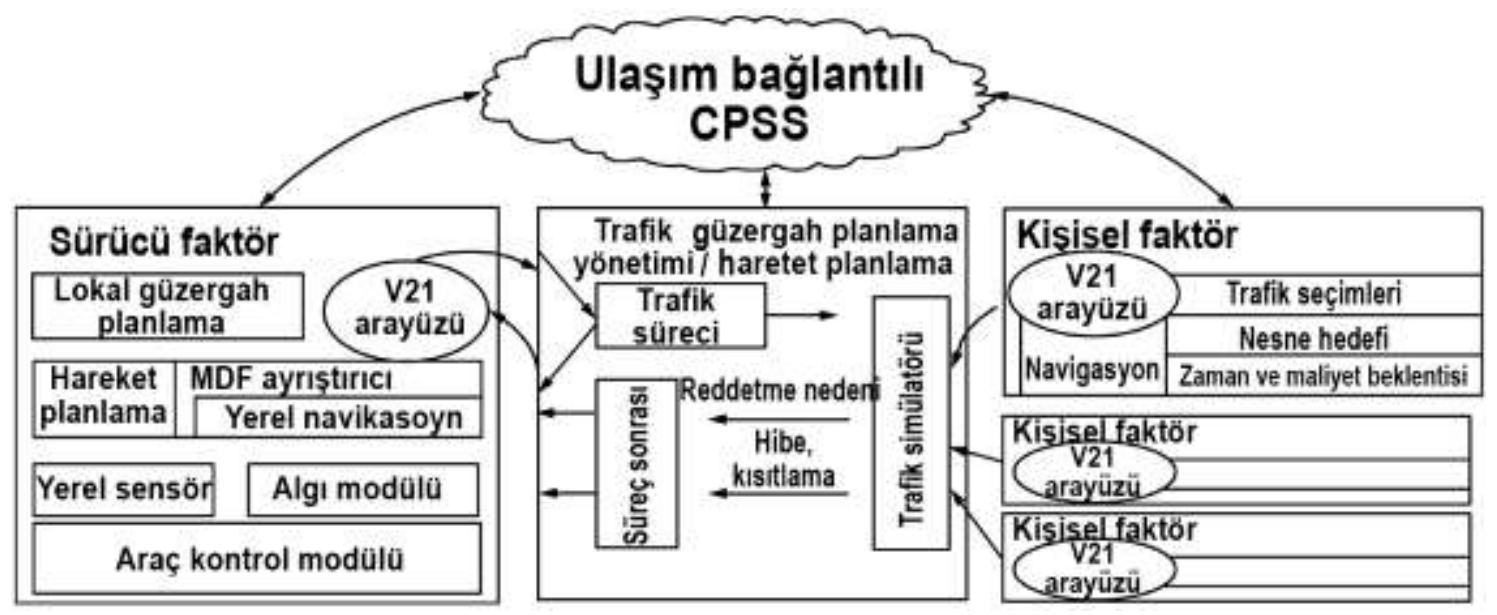

\section{e. Sosyal Ulaşım CPSS Taslağı}

Bir CPSS'te insanların sosyal sensörler olarak oynadığı rolü açıklayan Sayfa | 1523 Xiong vd., bir kentsel sosyal ulaşım sistemi olan Ulaşım 5.0'i tanıtmaktadırlar. Bu sistemde trafik kazaları, trafik sıkışıklığı gibi yönlendirme bilgilerini ile turistlerin ilgisini çekebilecek pazar yerleri ve seyahat ipuçları rehberlikle ilgili bilgileri paylaşabilen bilgiler örneğin, havaalanı rehberliğinde kullanılabilmektedir. Havaalanı ağı tarafından sağlanan hizmetler ve nesnelerle etkileşim kurabilen kullanıcl, sistemden bir talepte bulunulduğunda, kullanıcının profilindeki tercihlere göre yardımcı olabilecek mevcut tüm hizmetlerin bir listesi sunulabilmektedir. Şekil 10'da gösterildiği gibi kullanıcı, akıllı telefonu kullanarak her bir nesneyle etkileşime geçebilmektedir. Bir nesne de kullanıcının takvimindeki bir etkinliği veya fiziksel konumuna bağlı olarak uçak biniş saatleri gibi herhangi bir güncellemeyi, hizmet derecelendirmelerini, kullanıcının geçmişi, seyahat hedefi vb. ile iletişimi geçmektedir. Böylece tüm görevlerin birleştirildiği bu CPSS, kullanıcının seyahat kararları, yol veya hangi restoran tercihine dair karar vermesinde yardımcı olmaktadır (Xiong vd., 2015: 328).

\section{f. Tahliye Davranışını Tahmin Etme CPSS Taslağı}

Yangın sırasında binaları tahliye etmeye yardımcı olmada kullanılabilecek CPSS'te Hu vd., insan davranışlarını modellemektedir. Buradaki modellemedeki sosyal özellik, yangın sırasında tahliye edilenlerin 
psikolojik ve fizyolojik davranışlarını odağa almaktadır. Herkesin fiziksel ve psikolojik özellikleri göz önünde bulundurularak kalabalığın tahliye davranışını ve hareketini tahmin edilmesinin büyük bir etkiye sahip olabileceği düşüncesiyle geliştirilen CPSS'te gerçek zamanlı tahliyeye rehberlik etmek istenmektedir. Şekil 11 'deki gibi gerçek dünya uygulamalarında, öğrenme ve eğitim için gerçek tahliye sistemini taklit etmek için yapay tahliye sistemlerinin kullanabileceğini söylemektedirler

Şekil 11: Tahliye davranışı tahmin CPSS taslağı (Hu vd., 2014: 51)

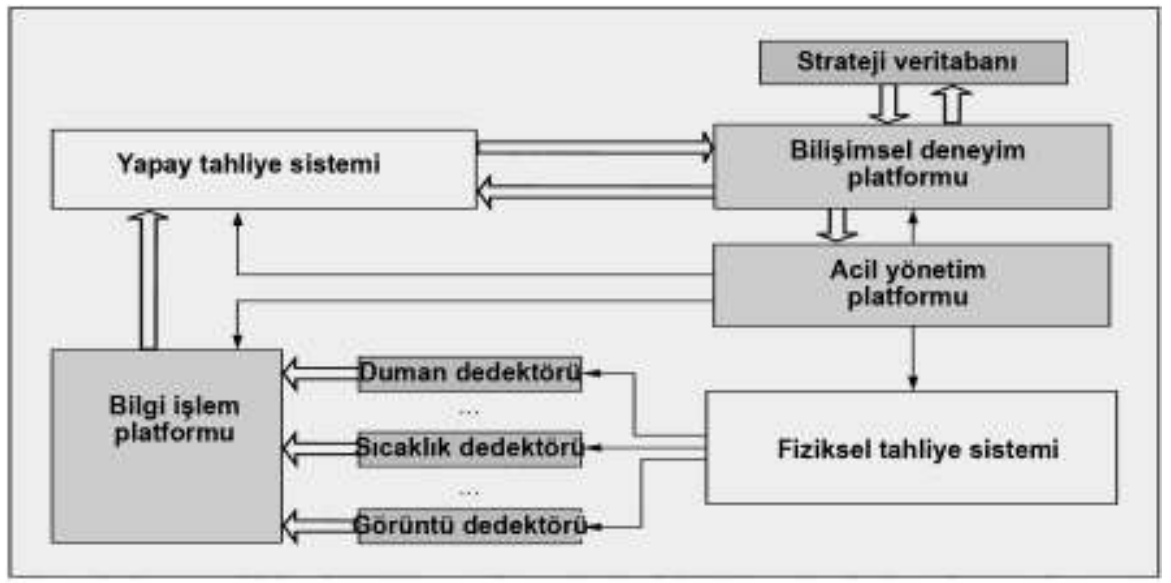

Yapay sistemlere sahip bilgisayarlarda tahliye edilenlerin davranışlarının önceden analiz edilmesi veya değerlendirilmesi yoluyla, Sayfa | 1524 gerçek tahliye sürecinde performansın iyileştirebilirliğini ve aynı zamanda, gerçek sensörlerle toplanan çeşitli verilerle yapay tahliye sistemleri kalibre edilerek gerçek zamanlı, gerçek tahliye süreçlerinde de kullanılabileceğini ortaya koymaktadırlar (Hu vd., 2014: 50-51).

\section{CPSS'in Yönetimsel Yeteneklere Etkisi}

Yukarıdaki örneklerden yola çıkarak CPSS'in tüm insan etkileşimleri ile komuta, kontrol ve hesaplama birimlerinin tamamının siber-fiziksel bir ortamda birleştirilmesiyle ortaya çıkarılan sistemler bütünü olduğu söylenebilir şeklinde bir tanımlama yapılabilir. Bu sistemde insanlar hem karar verici hem hizmet tüketicisi hem de işbirlikçi olmaktadır. Sensör verilerinden beslenmesinin yanı sıra CPSS'nin ayırt edici bir özelliği de müşteri geri bildirimi, sosyal tercihler, duygusal durum veya kişisel program verilerini içeren mobil uygulamalar aracılığıyla da kişiye özel sosyal verileri yakalayabilmesidir. Böyle bir mekanizmanın verimli bir şekilde çalışması, ajan hizmetlerinin sürekli güncellenmesini gerektirmektedir. Bu ise kullanıcı bildirimi, sürücü profilleri ve benzer ilgi veya alışkanlıkların kesintisiz toplanmasıyla mümkündür (Ding ve Jiang, 2016; Smirnov vd., 2015; Wang vd., 2016; Sabou ve Musil, 2018). Ağa bağlı bilgisayarların, insanların iletişim kurma ve bilgiyi yönetme şeklini, internetin de insanların bilgiyle 
etkileşim biçimini değiştirmesi gibi CPSS de insanların tasarlanmış sistemlerle etkileşim biçimini değiştirdiği açıktır (Murakami, 2013: 20). Bu nedenle bilgi devriminin etkisini gölgede bırakabilecek bir yeniliği beklemek gerekir (Gill, 2008: 3). CPSS'in tipik uygulama alanları akıllı ulaşım, akıllı bina, akıllı şehir ve akıllı fabrikanın yanı sıra sürüş ve sürücünün desteklenesi, transferler, trafik akışının iyileştirilmesi, binalarda acil durum tahliyesi ve verimli enerji kullanımı, vatandaş yönlendirmeleri, diğer riskleri azaltmak için uyarılarda bulunma ve fabrikada müşteri ve işletmelerin iş birliği için bir araya gelmesi, çalışanların insan- makine etkileşimi ile refahının, sağlığının ve çalışma atmosferinin iyileştirilmesi yönünde desteklenmesi alanlarında insan kabiliyetlerini önemli orana arttırmaktadır (Sabou ve Musil, 2018: 55).

Şekil 12: Karmaşık sistemlerin yönetimi ve kontrolü için CPSS tabanlı paralel yürütme (Wang vd., 2018'den Türkçeye çevrilerek alınmıştır).

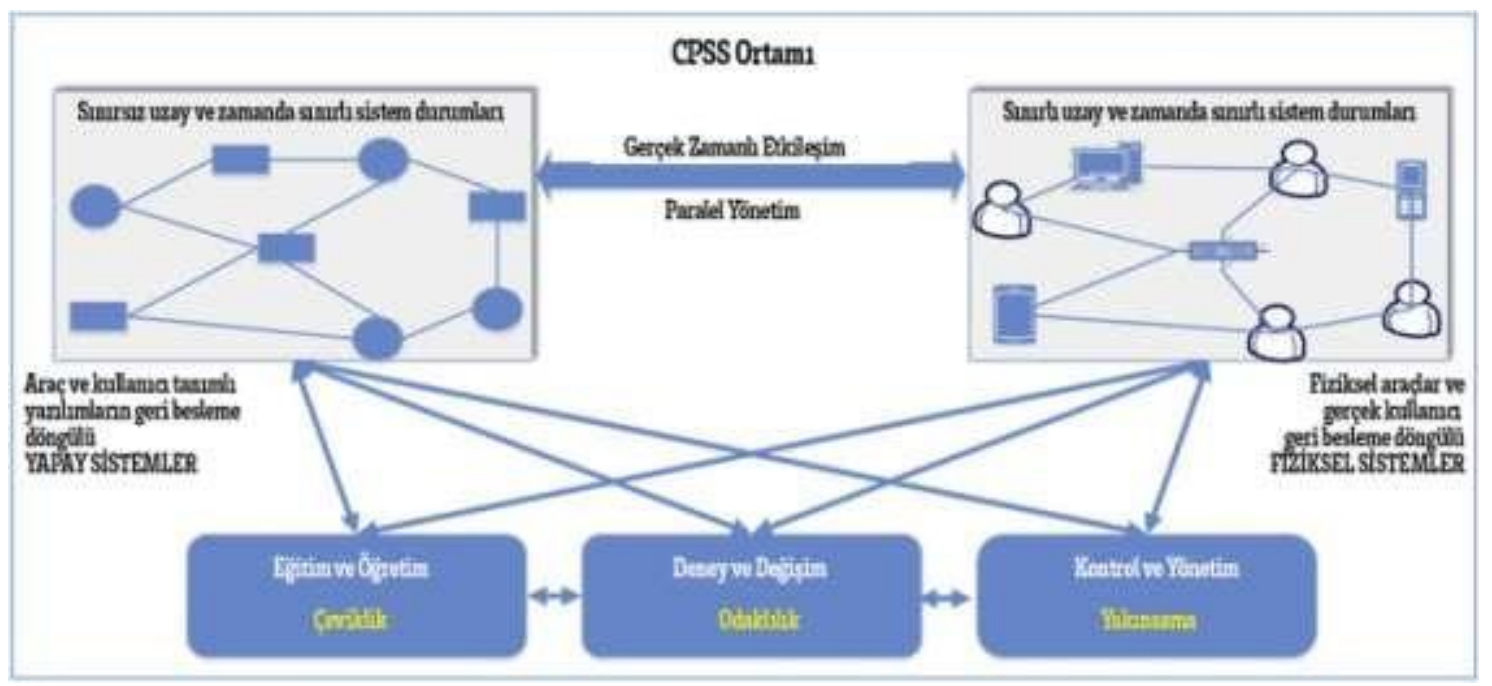

Sayfa | 1525

Şekil 12 'de CPSS ortamının farklı uzay ve zaman durumlarında yapay ve fiziksel sistemlerin gerçek zamanlı etkileşimi ve paralel yürütülmesi paralel zekâ, sosyal politikalar, ekonomik stratejiler ve hatta askeri operasyonları doğrulamak için bilişimsel deneylerden faydalanabilmesini getirmektedir. Burada yapay sistemlerin kararların fiziksel toplumda yürütülmeden önce hesaplandığı sosyal laboratuvarlar rolünü oynaması (Wang vd., 2016: 378) hem sosyal karmaşıklığa hem de mühendislik karmaşıklığına sahip sorunların üstesinden gelmede etkili çözümler sunmaktadır. Bu haliyle CPSS Newton'un mekanik sistemlerinin geleneksel araştırma perspektifinden kendi kendini uygulayan ve kendi kendini gerçekleştiren Merton'ın karmaşık sistem teorisine doğru bir paradigma değişimini temsil etmektedir. Bu durum dikkate alındığında Merton'ın, karmaşık sistemlerle ilgili olarak kesin sonuçlara varmanın yerine, sınırları belirlenmiş bir alan üzerinden verilere dayanan genellemelerle de empirik 
sonuçlara varılabileceğini göstermektedir. Burada küçük verilere dayanan büyük ve evrensel yasalar yerine, büyük verilere dayalı çok sayıda küçük ve özel yasalar devrededir. Ayrıca CPSS, Merton'ın insanı değer yaratan, yarattığı bu değerler paralelinde hedefe götürecek araçları akılcı biçimde seçebilen, yine de hislerinden ayrı düşünülemeyen varlık olarak tanımlamasına uygundur (Erkilet, 2007: 72).

\section{ACP Yaklaşımının Sosyal Bilimlere ve Toplum 5.0'a Yönelik Analizi}

Yukarıdaki açıklamalar ACP yaklaşımının, geleneksel yöntemlerle başa çıkılamayan sorunların çözümünde etkili olduğunu göstermektedir. Çünkü CPSS'ler modelleme, analiz ve kontrole yönelik koordinatif araştırma ve sistematik çabanın ürünüdür. Matematiksel modellere ve varsayımlara dayanan simülasyon yöntemleri, gerçek sistemlerin çoğu faktörünü yeniden üretip açıklayamazken siber uzay, fiziksel alan, bilişsel yetenekler ve sosyokültürel unsurları içeren CPSS paralel kontrol ve yönetim için simülasyon benzeri çözümler sunabilmektedir (Xiong vd., 2015: 328).

Şekil 13: ACP ve CPSS destekli paralel zeka ile ulaşılacağı öngörülen Toplum 5.0 taslağı

(Wang vd. 2018'den Türkçeye çevrilerek alınmıştır).

\section{Nakliyat 5.0, Tarım 5.0, Zekâ 5.0, Komuta ve Kontrol 5.0...}
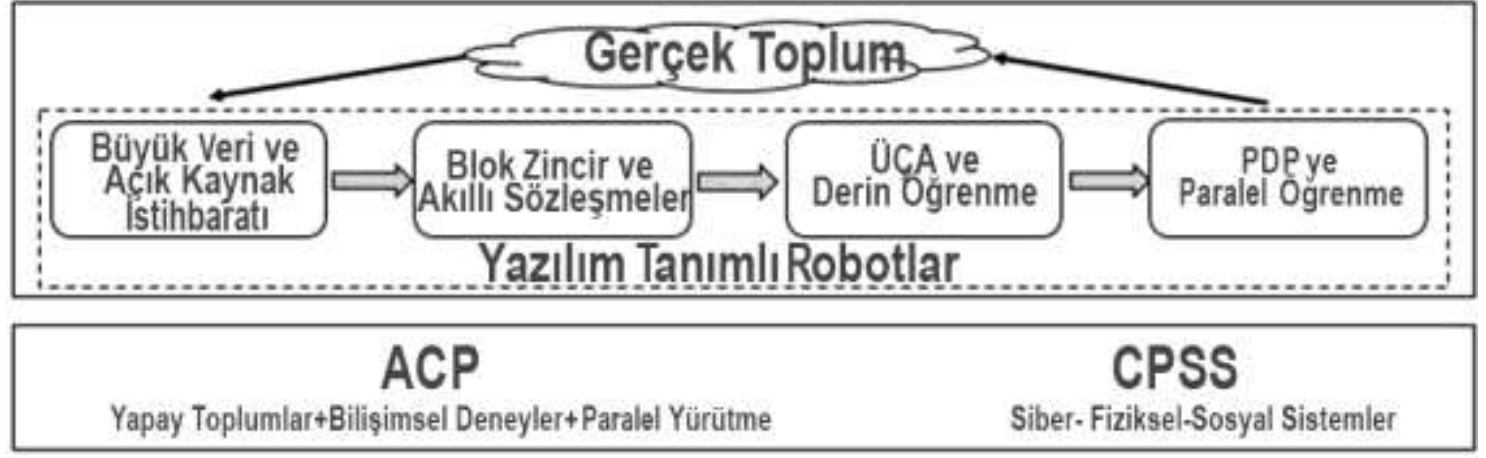

\section{Paralel Zekâ}

Şekil 13'te verildiği gibi yazılım tabanlı robotlar, yani büyük veri, açık kaynaklı istihbarat, block zincir, akıllı sözleşmeler, üretken çekişmeli ağlar (ÜÇA) ve paralel dinamik programlama (PDP) ile paralel öğrenme gibi unsurlar gerçek toplum için hem veri sağlama ve bilgiyi uygulama hem de geri bildirim araçları olarak kullanılabilmektedir. Böylece sosyal ihtiyaçları keşfederek veriler zekâya dönüştürülmektedir. Sonuçta açıklayıcı, hesaplanabilir ve yürütülebilir bir yol oluşturmak için ACP tabanlı sosyal 
bilişim yöntemiyle CPSS'teki yapay toplumlar ile gerçek fiziksel toplum arasındaki modelleme boşluğu doldurulabilmektedir. Bu şekilde ulaşılan çözüm üreten paralel zekâ siber hareket organizasyonları aracılığıyla fiziksel alan ile siber uzay arasında oluşan etkileşim, insanların görev tabanlı hizmetlere katılmak için yeni kalabalık zekâsı biçimlerini üretmektedir. Bu zekâ insanın geniş çeşitliliğinin ve bireysel etkileşimlerinin mikro bir görünümde gözlemleme imkânı veren bilişimsel hesaplamalar yoluyla sosyal davranışların analiz edilebilmesinden kaynaklanmaktadır. Küresel ısınma, doğal kaynakların kıtlığı, terörizm ve ekonomik ayrışma gibi küresel zorluklarla karşı karşıya olan dünyanın bu zekâdan faydalanması kaçınılmazdır.

BİT'teki ilerlemeye paralel olarak sanal-gerçek zekâ teknolojisinin odağında girilen yeni gelişme çağı, ACP yaklaşımıyla oluşturulan bu işbirlikçi zekâyla daha ileriye taşınabilir. Dolayısıyla dijital teknolojinin ve sanal ağların potansiyelinin kullanıldığı bu sistemde farklı sektör, ülke, bölge ve toplumun birbirine bağlanarak belirsiz, çeşitli ve karmaşık sorunlara çevik, odaklanmış ve yakınsak çözümler sunulabilir. YZ teknolojisinin bir sonraki aşaması olarak görülen CPSS'in çeşitli değer türlerini birbirine bağlaması, insanların emniyet, güvenlik ve rahatlık içinde yaşayabildiği sürdürülebilir süper akıllı toplum olan Toplum 5.0'da yönetim ve kontrole dair bir şans Sayfa| 1527 olarak görülebilir (Pereira vd., 2020). BİT'in gelişmesiyle birlikte büyük hesaplama imkânlarının oluşması ve mobil akıllı cihazların yaygın kullanımının insanların davranışlarına rehberlik edilebilmesi toplum gibi süper karmaşık sistemlerin modellenebilmesi sağlamıştır. Temelinde BİT'in ve CPSS teknolojisinin bulunduğu, farklı ontolojiye sahip üç farklı disiplinin bir araya getirilmesiyle oluşturulan ACP yaklaşımının Toplum 5.0'da biyolojik evrimde tanımlanabilecek yapıların ve süreçlerin taklit edilerek ekonomik ilerlemeyi, sosyal problemleri çözmek veya toplumu dengede tutmak için kullanılması mümkündür. Bu sonuç ACP yaklaşımının hem bilişim araçlarını kullanarak bir toplumun modellenmesi yoluyla deney ve gözlem yapmaya uygun hale getirilebildiğini hem de tasarlanarak oluşturulmak istenen Toplum 5.0'a uygunluğunu göstermektedir.

\section{SONUÇ}

Endüstri 4.0'ın etkileri halen devam etmesine rağmen modern dönemin başından beri üretim verimliliğine odaklanılarak bireyin göz ardı edilmesi Toplum 5.0 kapsamında tespit edilen en önemli sorundur. Bu nedenle bireylerin bilişsel ve fiziksel yeteneklerine etki ederek onların ekonomik ve sosyal değer üretiminde aktif rol almaları istenmektedir. Bu kapsamda insani yetenekleri arttıran teknolojiden destek alınarak bireylerin 
kendi çözümlerini oluşturması bir çözüm gibi görünmektedir. Böylece bireyler istedikleri tarzda bir yaşam sürdürmeleri mümkün görünmektedir. Üç farklı sistemin birleştirilmesiyle oluşturulan ve yeni nesil YZ olarak da anılan CPSS ile yine üç farklı disiplinin bir araya getirilmesiyle geliştirilen bir bilim alanı olan ACP yaklaşımının yönetim ve kontrol sorunları için etkili bilimsel çözümler sunarak bireylerin kabiliyetlerini desteklemektedir. Yeni geleceğin habercisi sayılabilen bu multidisipliner yaklaşımla oluşturulan sistemde bireysel ve toplumsal etkileşimlerin mikro bir görünümde modellenerek gözlemlenmesi ve bir işbirlikçi zekâ yardımıyla işlenerek Toplum 5.0'ın tasarlanması da sağlanabilir.

Öte yandan bu çalışma, bilişim bilimi alanında sosyal bilimler ile doğa bilimlerinin birçok yönünün iç içe geçmiş olmasından dolayı multidisipliner çalışma ortamlarının oluşturulmasının önceki dönemlerden daha önemli hale geldiğini göstermektedir. Proje bazlı çalışmalarda farklı alanlardan bilim insanları birlikte çalışabilmeleri teşvik edilmelidir. Son olarak ACP yaklaşımının her ne kadar sosyal bilimlere laboratuvar ortamında deney ve gözlem yapabilme imkânını hazırladığı bu çalışmayla ortaya konulmuş olsa da teknik düzlemde geliştirilmesi mühendislik alanının desteğine intiyaç bulunmaktadır. Bu nedenle sosyal bilimlerle mühendislik bilimi her düzeyde ortaklaşmalıdır.

Sayfa | 1528

\section{KAYNAKÇA}

Adjepon-Yamoah, D. E. (2012). A Tool to Support Teaching of Concurrent Programming. Newcastle University.

Bagheri, B., Yang, S., Kao, H.-A., \& Lee, J. (2015). Cyber-physical Systems Architecture for Self-Aware Machines in Industry 4.0 Environment. ScienceDirect, 1622-1627.

Bell, D. (2012). İdeolojinin Sonu. Ankara: Sentez Yayınları. Caner, G. (2020, Aralık). Dijital İkiz. Bilim ve Teknik, 44.

Castells, M. (2003). Enformasyon Çağı: Ekonomi, Toplum ve Kültür - Cilt 1. İstanbul: Bilgi Üniversitesi Yayınları.

Costanzo, A., Faro, A., Giordano, D., \& Spam, C. (2016). An Ontological Ubiquitous City Information Platform Provided with Cyber-Physical- SocialSystems. 13th IEEE Annual Consumer Communications \& Networking Conference (CCNC), (s. 137-144). Las Vegas: IEEE.

CRDS. (2016). Future Services \& Societal Systems in Society 5.0. Tokyo: CRDS: Center for Research and Development Strategy-Japan Science and Technology Agency. 
Ding, K., \& Jiang, P. (2016). Incorporating Social Sensors and CPS Nodes for Personalized Production under Social Manufacturing Environment. ScienceDirect, 366-371.

DPT. (2008). Dünya Bilgi Toplumu Zirvesi. Ankara: Devlet Planlama Teşkilat, Bilgi Toplumu Dairesi Başkanlığı.

Epstein, J. M., \& Axtell, R. (1996). Artificial Societies - Social Science From The Bottom Up. Washington: The Brookings Institution.

Erkilet, A. (2007). Toplumsal Yapı ve Değişme Kuramları: Sorokin, Parsons, Dahrendorf, Merton. Ankara: Hece Yayınları.

Fukuyama, M. (2018). Society 5.0: Aiming for a New Human-Centered Society. SPOTLIGHT, 47-50.

Gill, H. (2008). From Vision to Reality: Cyber-Physical Systems. HCSS National Workshop on New Research Directions for High Confidence Transportation CPS: Automotive, Aviation, and Rail (s. 1-29). NITRD High Confidence Software and Systems Coordinating Group.

Harari, Y. N. (2016). Homo Deus. İstanbul: Kolektif Kitap.

Hu, Y., Wang, F.-Y., \& Liu, X. (2014). A CPSS Approach for Emergency Evacuation in Building Fires. IEEE Computer Society, 48-52.

Humayed, A., Lin, J., Li, F., \& Luo, B. (2017). Cyber-Physical Systems Security - A Survey. arXiv:CS.CR, 1-12.

Işıklı, Ş., \& Küçükvardar, M. (2016). Bilişim Devrimi - Teknolojinin Felsefi ve Sosyolojik Analizi. Ankara: Birleşik Yayınevi.

İyigüngör, W. (2015). Karl Popper ve Jürgen Habermas'ın Üç Dünya Teorileri Üzerine Bir Değerlendirme. Marmara İletişim Dergisi, 49-59.

Jørgensen, J. B. (2021). Erişim Adresi: imm.dtu.dk: http://www.imm.dtu.dk/ jbjo/cps.html Erişim Tarihi: 06.01.2021.

KEIDANREN. (2016). Toward Realization of the New Eeconomy and Society - Outline. Tokyo: KEIDANREN.

Kydland, F. E., \& Prescott, E. C. (1996). The Computational Experiment: An Econometric Tool. Journal of Economic Perspectives, 69-85.

Microsoft. (2007, Kasım 12). Parallel Computing: Background. Erişim Adresi: microsoftpost.com: http://www.microsoftpost.com/2409/microsoft-download/the- manycoreshift-white-paper/ Erişim Tarihi: 03.02.2021.

More, T. (2000). Ütopia. İstanbul: Kaynak Yayınları. 
Murakami, K. J. (2013). CPSS (Cyber-Physıcal-Socıal System) Initiative Beyond CPS (Cyber-Physıcal System) for a Better Future. Japan: Kyushu University \& ISIT/Kyushu.

Nair, G. (2018). Bilişim Kültürünün Toplum Üzerinde Etkisi ve Yeni İnsan Tipinin Doğuşu. CÜ Sosyal Bilimler Dergisi 42,39-53.

Nakanishi, H., \& Kitano, H. (2018). Society 5.0 - Co-creating the future.

Tokyo: Keidanren.

Öztürk, F. (2021). İnsanlık Yararına Teknolojik Dönüşüm: Toplum 5.0. Bilim ve Teknik, 30-39.

Pereira, A. G., Lima, T. M., \& Charrua-Santos, F. (2020). Industry 4.0 and Society 5.0: Opportunities and Threats. International Journal of Recent Technology and Engineering, 3305-3308.

Sabou, M., \& Musil, A. (2018). Cyber-Physical Social Systems for City-wide Infrastructures. FFG.

Sacks, J., Welch, W. J., Mitchell, T. J., \& Wynn, H. P. (1989). Design and Analysis of Computer Experiments. Stastical Sience, 409-435.

Salgues, B. (2018). Society 5.0: Industry of the Future, Technologies, Methods and Tools. Londra: ISTE.

Smirnov, A., Levashova, T., \& Shilov, N. (2015). Online Communities for Agent Collaboration in Cyber-Physical-Social Systems. St. Petersburg: ITMO University.

Şimşek, A. (2012). Sosyal Bilimlerde Araştırma Yöntemleri. Eskişehir: Anadolu Üniversitesi.

Tankovska, H. (2021, Şubat 25). Erişim Adresi: statista.com: https://www.statista.com/topics/1164/social-

networks/\#dossierSummary Erişim Tarihi: 05.05.2021.

Toffler, A. (2008). Üçüncü Dalga. İstanbul: Koridor Yayıncılık.

Wang, F.-Y. (2007). Toward a Paradigm Shift in Social Computing: The ACP Approach. IEEE Computer Society, 65-67.

Wang, F.-Y., Yuan, Y., Wang, X., \& Qin, R. (2018). Societies 5.0: A New Paradigm for Computational Social Systems Research. IEEE Transactions On Computational Social Systems, 2-8.

Wang, X., Li, L., Yuan, Y., Ye, P., \& Wang, F.-Y. (2016). ACP-Based Social Computing and Parallel Intelligence: Societies 5.0 and Beyond. ScienceDirect, 377-393. 
Xie, C. (2010). Computational Experiments for Science and Engineering Education. MODSIM World Conference and Expo (s. 1-11). Virginia: ResearchGate.

Xiong, G., Zhu, F., Liu, X., Dong, X., \& Huang, W. (2015). Cyber-physicalsocial System in Intelligent Transportation. IEEE/CAA JOURNAL OF AUTOMATICA SINICA, 320-333.

Yeşilorman, M., \& Koç, F. (2014). Bilgi Toplumunun Teknolojik Temelleri Üzerine Eleştirel Bir Bakış. Fırat Üniversitesi Sosyal Bilimler Dergisi, 117133.

Yılmaz, A., \& Yazıcı, S. (2017). Sosyal Bilimler Felsefesinde Temel Sorunlar ve Yaklaşımlar. Liberal Düşünce Dergisi, 57-68.

Wikipedia (2021). Erişim Adresi: wikipedia.org:

https://tr. wikipedia.org/wiki/B\%C3\%BCy\%C3\%BCk veri Erişim Tarihi: 12.05.2021.

GENIŞ̧LETILMİ̧̧ ÖZET: Bu araştırma kapsamında süper akıllı toplum olarak tabir edilen Toplum 5.0'ın gerçekleştirilebilirliğini destekleyebilecek bir yaklaşım olan ACP yöntemi analiz edilmektedir. Bunun yanında bir sosyal sistem inşası olan Toplum 5.0'ın tasarlanarak geliştirilmesinin planlanması bu geleceğin deney ve gözleme dayandığını ortaya koymaktadır. Bu nedenle Toplum 5.0'ın inşasında kullanılabilecek yöntemin sosyal bilimler alanında da deney ve gözlem yapma Sayfa | 1531 imkanını sunacağı düşünülmektedir. Japonya'da bir politika önerisi olarak geliştirildikten sonra süregelen sosyal sorunların global çözüm yolu şeklinde dünyaya tanıtılan Toplum 5.0'ın bu iddiaya sahip olması konuyu araştırmaya değer kılmaktadır. Buna yönelik bilgi ve belgelerin analiz edilerek yardımcı unsurların oluşturulması Toplum 5.0 iddiasının gerçekleştirilebilmesi olasılı̆ına pozitif etkide bulunacaktır. Bu nedenle söz konusu hedefe ulaştırabildiğini yardımcı olacağı düşünülen ACP yaklaşımını analiz etmek bu araştırmanın konusunu oluşturmaktadır. Böylece Toplum 5.0'ın inşasına yardımcı olabilecek bir yaklaşım açıklanırken sosyal bilimlerin deney ve gözleme dayalı araştırmalar yapabilmesini sağlayan bir yönteme de ulaşılmaktadır. Geniş bir arka plan araştırması sonucunda şu hipotez geliştirilerek kanıtlanmaya çalışııış̧ır: Bireysel kurumsal ve yönetimsel yeteneklerin ACP yaklaşımı ile geliştirilebilmesi Toplum 5.0 gibi bir sosyal sistemin tasarımını mümkün kılmaktadır. Günümüzde Endüstri 4.0'ın enstrümanı olan CPS teknolojisinin toplumsal ve ekonomik işleyişin her katmanında kabul edilmesi nedeniyle bir üst versiyonu sayılan CPSS teknolojisinin de toplum tarafından kabul göreceği varsayılmaktadır. Analitik bir yaklaşımla, nitel araştırma teknikleri kullanılarak yapılan bu araştırmada elektronik ve yazıı kaynaklar taranmıştır. Belirlenen anahtar kelimeler yardımıyla ulaşılan kaynaklar incelenerek ilgili veriler ayıklanmış, gerekli alıntılar, uygun atıflar yapılarak alınmıştır. Burada bilgisayar ve internet teknolojisinden, özellikle açık kaynak verilere ulaşılmasında yararlanıımıştır. Geniş bir literatürün titizlikle tarandığı bu çalışmada siber-fiziksel sistemler (CPS; Cyber - Physical Systems) ve siber-fiziksel-sosyal sistemler (CPSS; 
Cyber - Physical - Social - Systems) gibi yapay toplum - bilişimsel deneyler paralel yürütme şeklinde ifade edilebilen ACP (Artifical Society-Computational Experiment-Parallel Execution) yaklaşımına alt yapı oluşturan teknolojiler incelenmektedir. Çalışmanın sonucunda Merton yasası, sosyal bilişim ve paralel zekâ üçgeninde insan- bilgisayar etkileşimin ACP yaklaşımıyla siber-fiziksel dünyadaki etkisi görünür hale getirilmektedir. Transhumanizm, dijitalleşme ve Endüstri 4.0 kavramlara eşdeğer bir kavram olabilecek nitelikteki Toplum 5.0'la ilgili yapılan bu katkı, hem sosyal bilimlerde yaşanan deney ve gözlem yapabilme sıkıntısına bir çözüm sunmakta hem de disiplinlerarası bilimsel çalışmalar ve uluslararası stratejik adımlara kavramsal bir köprü oluşturmaktadır. Sonuç olarak ACP yaklaşımı ve CPSS teknolojilerinin Toplum 5.0'ın gerçekleştirilebilirliğine olan etkisinin açıklandığı çalışmada Sosyal Bilişim biliminin sınırları içinde kalınarak ACP yaklaşımının ve CPSS teknolojisinin Toplum 5.0'a ulaşılmasında yararlanılabilecek bir yöntem olarak kullanılabilirliği uygulama örnekleri ile kanıtlanmaktadır. Bu bilimin dışında kalan ekonomik ya da mühendislik alanları konunun kapsamı dışında bırakılmıştır. Öte yandan bu araştırma nitel araştırma yöntemlerinden alan taraması yöntemine göre gerçekleştirilmiştir. Dolayısıyla tarama modellerinde genel olarak var olan (Şimşek, 2012: 91) durum ya da gerçekliğin olduğu gibi araştırılıp açıklanarak nesneye, olguya, olaya, bireye vb. ilişkin günümüzdeki ya da geçmişteki verilerin tamamı gözden geçirilmeye çalışımıştır. Burada araştırılan olguya ilişkin dağınık veriler toparlanıp sınıflandııımış ve düzenlenerek çözümlenmiştir. Böylece Sosyoloji, Sosyal Bilişim ve İletişim alanlarında yapılacak Sayfa | 1532 teknolojik toplum çalışmaları için literatüre katkı olarak eklenen bilimsel akademik bir çalışmaya ulaşılmıştır. İnceleyici bir yaklaşımla literatürdeki veriler titiz bir biçimde toplanıp analiz edilerek ulaşılan bulgularda transhumanizm, dijitalleşme ve Endüstri 4.0 kavramlarına eşdeğer, yeni ve güçlü kavramlar olan akıllı toplum ve Toplum 5.0'ın gelecek süper akıllı toplumuna ulaşılması için kullanılabilecek Türkçe literatürde ilk ve tek çalışma olması önemli bir özgün değerdir. Bunun yanında bilişim sistemlerinin sunduğu imkânlarla sosyal bilimlere deney ve gözleme dayalı bir yöntemi açıklaması da önemli bir özgün değer sayılmaktadır. Endüstri 4.0'ın etkileri daha devam etmesine rağmen modern dönemin başından beri üretim verimliliğine odaklanılarak bireyin göz ardı edilmesi Toplum 5.0 kapsamında tespit edilen en önemli sorundur. Bireylerin bilişsel ve fiziksel yeteneklerine etki ederek onların yeni değerleri üretebilmesini sağlayan CPSS teknolojisiyle bireylerin kendi çözümlerini oluşturarak istedikleri tartsa bir yaşam sürdürmeleri mümkün görünmektedir. Yeni nesil YZ olarak da görülen CPSS üç farklı sistemin birleştirilmesiyle oluşturulmuştur. Yine üç farklı disiplinin bir araya getirilmesiyle geliştirilen bir bilim alanı olan ACP'nin kuralları içinde yönetim ve kontrol sorunları için etkili bilimsel çözümlerin oluşturulabilmektedir. Yeni geleceğin habercisi sayılabilen bu multidisipliner yaklaşımla oluşturulan sistemde bireysel ve toplumsal etkileşimlerin mikro bir görünümde modellenerek gözlemlenmesi ve bir işbirlikçi zekâ yardımıyla işlenerek Toplum 5.0'ın tasarlanması sağlanabilir. Öte yandan bu çalışma sonucunda, bilişim bilimin alanında sosyal bilimlerin ve doğa bilimlerinin birçok yönünün iç içe geçmiş 
olmasından dolayı multidisipliner çalışma ortamlarının oluşturulmasının önceki dönemlerden daha önemli hale geldiği anlaşılmaktadır. Proje bazlı araştırmalarda farklı alanlardan bilim insanları birlikte çalışabilmeleri teşvik edilmelidir. Son olarak ACP yaklaşımının her ne kadar sosyal bilimlere laboratuvar ortamında deney ve gözlem yapabilme imkânını hazırladığı bu çalışmayla ortaya konulmuş olsa da teknik düzlemde geliştirilmesi mühendislik alanının desteğine ihtiyaç bulunmaktadır. Bu nedenle sosyal bilimlerle mühendislik bilimi her düzeyde ortaklaşmalıdır.

EXTENDED ABSTRACT: Within the scope of this research, the ACP method, which is an approach that can support the feasibility of Society 5.0 , which is called supersmart society, is analyzed. In addition, the design and development of Society 5.0, which is a social system construction, reveals that this future is based on experimentation and observation. For this reason, it is thought that the method that can be used in the construction of Society 5.0 will provide the opportunity to make experiments and observations in the field of social sciences. The fact that Society 5.0, which was introduced to the world as a global solution to ongoing social problems after being developed as a policy proposal in Japan, has this claim makes the subject worth researching. The creation of auxiliary elements by analyzing the information and documents related to this will have a positive effect on the possibility of realizing the claim of Society 5.0. For this reason, it is the subject of this research to analyze the ACP approach, which is thought to help achieve the said goal. Thus, while explaining an approach that can help in the Sayfa | 1533 construction of Society 5.0, a method that enables social sciences to conduct research based on experiment and observation is also reached. As a result of extensive background research, the following hypothesis has been developed and tried to be proven: Developing individual institutional and managerial capabilities with the ACP approach makes it possible to design a social system such as Society 5.0. Since CPS technology, which is the instrument of Industry 4.0 , is accepted in every layer of social and economic functioning, it is assumed that CPSS technology, which is considered as an upper version, will also be accepted by the society. In this research, which was conducted using qualitative research techniques with an analytical approach, electronic and written sources were scanned. By examining the sources reached with the help of the determined keywords, the relevant data were extracted and the necessary citations were taken by making appropriate citations. Here, computer and internet technology, especially open source data, has been utilized. ACP, which can be expressed as artificial society - computational experiments - parallel execution, such as cyber-physical systems (CPS) and cyberphysical-social systems (CPSS) in this study, in which a wide literature was meticulously scanned. Technologies that form the basis of the (Artifical SocietyComputational Experiment-Parallel Execution) approach are examined. As a result of the study, the effect of human-computer interaction in the cyber-physical world in the triangle of Merton's law, social informatics and parallel intelligence is made visible with the ACP approach. This contribution to Society 5.0, which can be an equivalent concept to the concepts of transhumanism, digitalization and Industry 
4.0 , not only offers a solution to the problem of experimentation and observation in social sciences, but also creates a conceptual bridge to interdisciplinary scientific studies and international strategic steps. As a result, in the study, in which the effect of ACP approach and CPSS technologies on the feasibility of Society 5.0 is explained, the usability of ACP approach and CPSS technology as a method that can be used in reaching Society 5.0, while staying within the limits of Social Informatics science, is proven with application examples. Economic or engineering fields that are outside of this science are excluded from the scope of the subject. On the other hand, this research was carried out according to the field survey method, which is one of the qualitative research methods. Therefore, the situation or reality that exists in general in scanning models (Şimşek, 2012: 91) is investigated and explained as it is, and it can be defined as an object, phenomenon, event, individual, etc. All of the current or past data on the subject has been tried to be reviewed. Here, scattered data on the phenomenon investigated were collected, classified, organized and analyzed. Thus, a scientific academic study added as a contribution to the literature for technological society studies in the fields of Sociology, Social Informatics and Communication has been reached. It is important that smart society and Society 5.0, which are new and powerful concepts equivalent to the concepts of transhumanism, digitalization and Industry 4.0, are the first and only study in the Turkish literature that can be used to reach the future super-intelligent society is the original value. In addition, it is considered an important original value to explain a method based on experiment Sayfa | 1534 and observation to social sciences with the possibilities offered by information systems. Although the effects of Industry 4.0 still continue, the most important problem identified within the scope of Society 5.0 is to focus on production efficiency since the beginning of the modern period. With CPSS technology, which enables individuals to produce new values by influencing their cognitive and physical abilities, it seems possible for individuals to create their own solutions and lead a life as they wish. CPSS, which is also seen as a new generation AI, was created by combining three different systems. Effective scientific solutions for management and control problems can be created within the rules of ACP, which is a field of science developed by bringing together three different disciplines. In this system created with a multidisciplinary approach, which can be considered the harbinger of the new future, it is possible to observe individual and social interactions by modeling them in a micro view and to design Society 5.0 by processing them with the help of a collaborative intelligence. On the other hand, as a result of this study, it is understood that the creation of multidisciplinary working environments has become more important than in previous periods, since many aspects of social sciences and natural sciences are intertwined in the field of informatics. Scientists from different fields should be encouraged to work together in project- based research. Finally, although it has been demonstrated in this study that the ACP approach provides the opportunity for social sciences to conduct experiments and observations in a laboratory environment, its development on a 
technical level requires the support of the engineering field. For this reason, social sciences and engineering science should be common at all levels.

\section{EKLER}

Ekler 1: CPSS sistematik haritalama çalışması, İngilizce belge (Sabou vd., 2018)

\begin{tabular}{|c|c|}
\hline 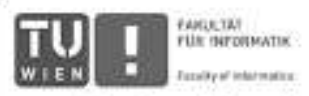 & COLLECTIVE INTELUGENCE 2018, Zunich, Switzertand, July 7.8, 2018 \\
\hline \multicolumn{2}{|c|}{$\begin{array}{c}\text { Collective Intelligence Aspects of Cyber-Physical Social Systems: } \\
\text { Results of a Systematic Mapping Study }\end{array}$} \\
\hline & $\begin{array}{l}\text { arta Sabou, Angelika Musil, Juergen Musil, Stefan Biffl } \\
\text { instume of Intomabon Systems Engnesering, Tu Wien, Vienna, Austria }\end{array}$ \\
\hline
\end{tabular}

\begin{tabular}{|c|c|}
\hline \multicolumn{2}{|c|}{ Context } \\
\hline $\begin{array}{l}\text { Cyber.Physical Social } \\
\text { Systoms (CPSS) span the } \\
\text { cyber, otysical and social } \\
\text { spoce. }\end{array}$ & 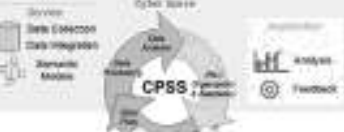 \\
\hline $\begin{array}{l}\text { Theses systems take into } \\
\text { accoumt human behavor and } \\
\text { provided social data and aim } \\
\text { to infuence both the physical } \\
\text { and the social space. }\end{array}$ & ${ }^{1}+\frac{1}{1}$ \\
\hline
\end{tabular}

\section{Research Questions}

RQ 1. CPSS Definition: What is an overarching defininon of CPSS? RQ 2 CPSS Concept: What are the main CPSS characteristics and processes?

RQ 3, CPSS Architecture: What archtectural aporoashes are applied to design and describe CPSS?

RQ 4. CPSS Research: What is the focus of current CPSS research? RQ 5. CPSS Application: What are typical application domains and concrete examples of CPSS?
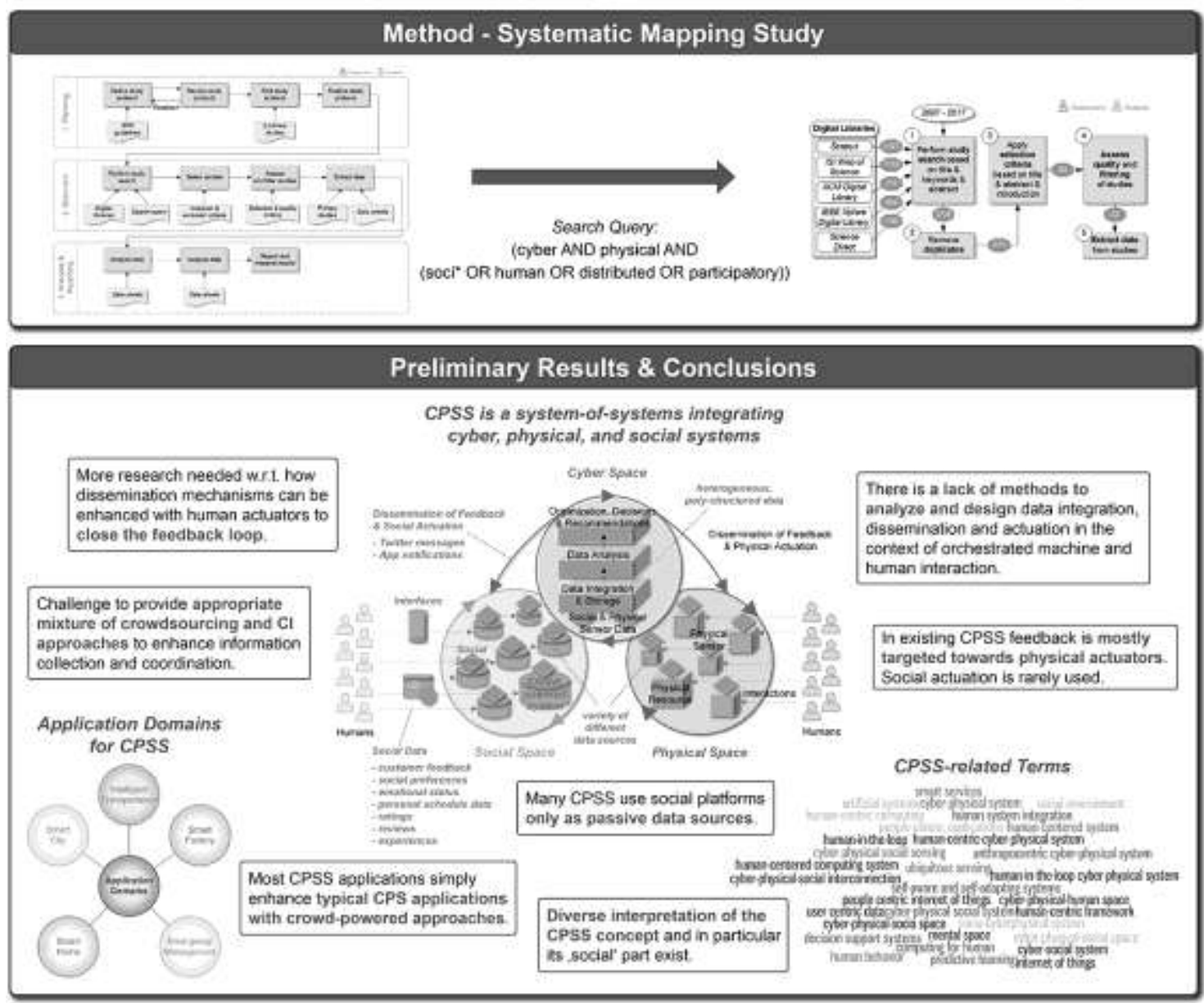

Comact: Marta Sabou

marta.sabcuBifs, tuwien ac at

hatp:liqse ifs tumien ac at 
Ek2: ACP yaklaşımına dayalı bilgi otomasyonu ve Newton sistemi ile Merton sistemi bilgi akışı görüntüsü, İngilizce taslak (Wang vd., 2016).
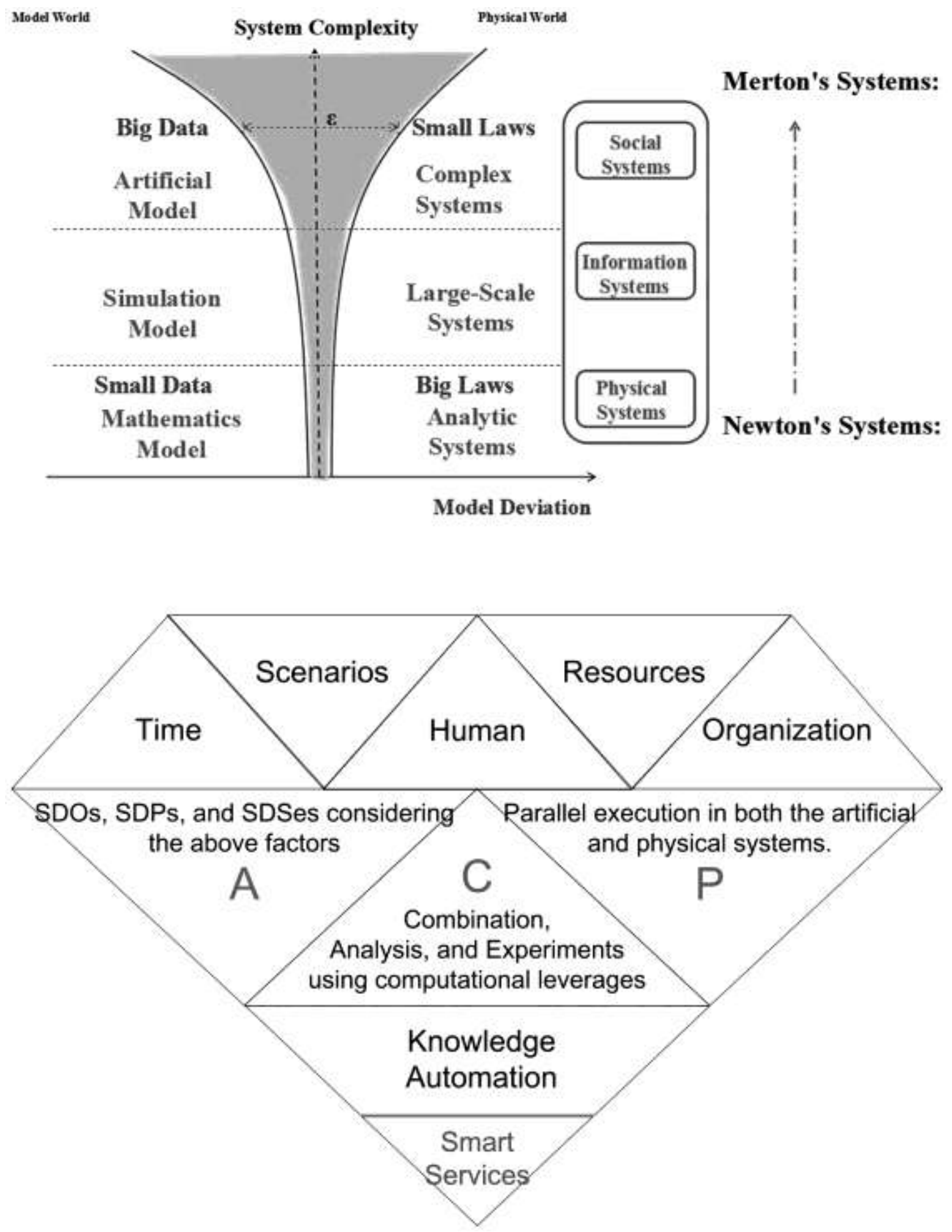

Sayfa | 1536

Ek3: CPSS teknolojisi ve ACP yaklaşımın arkapılanındaki kapalı döngü geri bildirimi ile yapılandırılabilir sosyal yönetim taslak görüntüsü, İngilizce belge (Wang vd., 2016) 


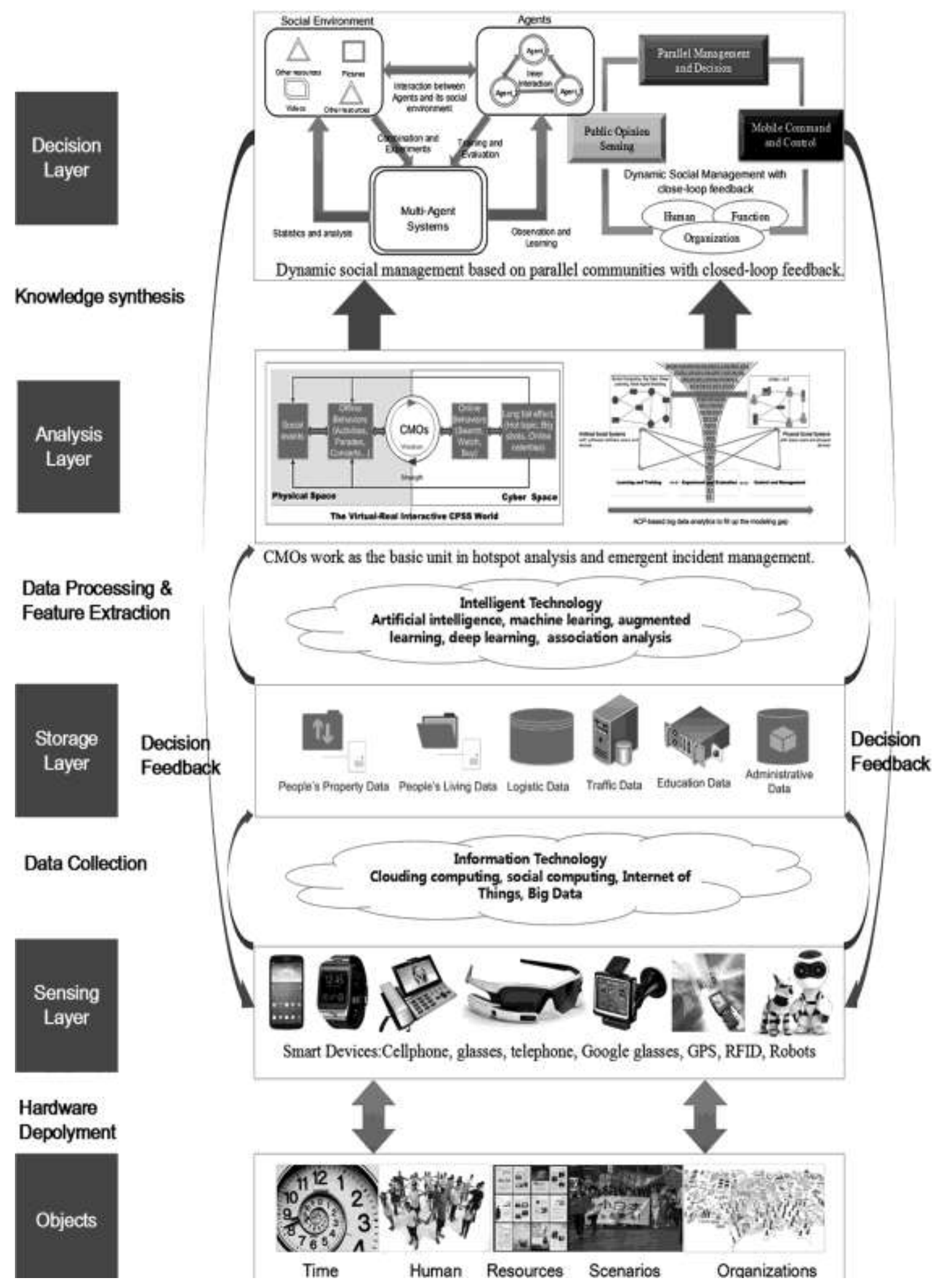

Sayfa | 1537 


\section{TABLOLAR LİSTESİ}

Tablo 1: Toplum 5.0 aşamasının karşılaştırmalı karakteristik özellikleri

Tablo 2: Endüstri 4.0'ו etkileyen teknolojik megatrendler ve alt grupları

Tablo 3: Akıllı toplumun özellikleri için gereksinimler

Tablo 4: Akıllı mutfak CPSS kullanışlılık testi

Tablo 5: Akıllı mutfak CPSS kullanışlılık test sonuçları

Tablo 6: Toplum 5.0 ve 2030'a kadar Japonya'da beklenen gelişmeler

\section{ŞEKİLLER LİSTESí}

Şekil 1 : Bir CPS'in genel şeması

Şekil 3 : Akıllı Endüstri'de kullanılan CPS şeması

Şekil 3 : CPS platformları şeması

Şekil 4 : Sistem odaklı ürün geliştirme biçimi: Dijital ikiz

Şekil 5 : Siber-Fiziksel-Sosyal Sistemin ana unsurları

Şekil 6 : Kişiselleştirilmiş üretim CPSS taslağı

Şekil 7 : Akıllı toplantı odası CPSS taslağı

Şekil 8 : Akıllı Seyahat CPSS taslağı

Şekil 9 : Kontrol ve Senkronizasyon CPSS taslağı

Şekil 10 : CPSS tabanlı akıllı sürüş taslağı

Şekil 11 : Tahliye davranışı tahmin CPSS taslağı

Şekil 12 : Karmaşık sistemlerin yönetimi ve kontrolü için CPSS tabanlı paralel

yürütme

Sayfa | 1538

Şekil 19 : ACP tabanlı paralel zekâ

Şekil 20 : Paralel zekâ ile öngörülen Toplum 5.0 taslağı

\section{KISALTMALAR}

ABD : Amerika Birleşik Devletleri

AİHM : Avrupa İnsan Hakları Mahkemesi

ACP : Artifical Society-Computational Experiment-Parallel Execution

Ar-Ge: Araştırma Geliştirme

AG : Arttırılmış Gerçeklik

API : Application Programing Interface/Uygulama Programlama arayüzü

BM : Birleşmiş Milletler

BM-SKH: Birleşmiş Milletler Sürdürülebilir Kalkınma Hedefleri

BİT : Bilgi İletişim Teknolojileri

BT : Bilgi Teknolojileri

CPS : Siber-Fiziksel Sistemler

CPSS : Siber Fiziksel-Sosyal Sistemler

EBA : Eğitim Bilişim Ağı

FAO : Food and Agriculture Organization (Gıda ve Tarım Örgütü)

IDC : International Data Corporation

KEIDANREN: Japonya İş Federasyonu

KVKK: Kişisel Verileri Koruma Kanunu

RFID : Radyo Frekansı Tanımlama (Radio Frequency Identification) 


\section{Sosyal Bilimlere Deney ve Gözlem İmkânı Sunan Bir Yöntem Önerisi: ACP Abdülkadir Büyükbingöl}

SDGs : Sustainable Development Goals

SKH : Sürdürülebilir Kalkınma Hedefleri

TC : Türkiye Cumhuriyeti

TCK : Türk Ceza Kanunu

UNDFF: The United Nations Decade for Family Farming

YZ : Yapay Zeka 
Sosyal Bilimlere Deney ve Gözlem İmkânı Sunan Bir Yöntem Önerisi: ACP Abdülkadir Büyükbingöl

Sayfa | 1540 Academy, Yıl 3, Year 3, Sayı 7, Issue 7, Aralık 2021, December 2021. 
Sosyal Bilimlere Deney ve Gözlem İmkânı Sunan Bir Yöntem Önerisi: ACP Abdülkadir Büyükbingöl

Sayfa | 1501 